\title{
THE INVESTIGATION OF TOXIC ELEMENT POLLUTION AND RADIOACTIVITY ANALYSES OF MARINE SEDIMENTS IN THE GULF OF GEMLIK (BURSA, TURKEY)
}

\author{
YÜMÜN, Z. Ü. ${ }^{1 *}-$ KAM, E. ${ }^{2}-$ DINÇER, A. R. ${ }^{1}-$ ÖNCE, M. ${ }^{1}-$ YÜMÜN, S. ${ }^{1}$ \\ ${ }^{1}$ Environmental Engineering Department, Çorlu Engineering Faculty, Namık Kemal University, \\ 59860 Çorlu, Tekirdağ, Turkey \\ (e-mail: adincer@nku.edu.tr; melike-once@hotmail.com;sevinc.yumun@gmail.com) \\ ${ }^{2}$ Physics Department, Faculty of Arts and Sciences, Yildiz Technical University, Davutpaşa \\ Campus, 34220 Esenler/Istanbul, Turkey \\ (e-mail: erolkam@yildiz.edu.tr) \\ *Corresponding author \\ e-mail:zyumun@nku.edu.tr
}

(Received $4^{\text {th }}$ Sep 2020; accepted $19^{\text {th }}$ Jan 2021)

\begin{abstract}
In this study, the Toxic element pollution and radioactivity of marine sediments in the Gulf of Gemlik was determined. Enrichment factor (EF) and Pollution index (PI) analyses have been applied to determine toxic element pollution. According to the enrichment factor results, the EFNi in BH-1 was between $3<\mathrm{EFNi}<5$, and the other EF values are all below 3. In radionuclide analysis, the Ra-226 and Th-232 values were found to be below the global average value in all locations. It is estimated that the K40 values, which are above the world average values in the BH-1 drillings, are due to the intensive agricultural activities in that part of the study area. Cs- 137 values were found to be $5.3 \mathrm{~Bq} / \mathrm{kg}$ in the $\mathrm{BH}$ $1 / 1$ drilling location. This finding is very important in terms of environmental pollution. In other locations, samples have been found to be below the Cs-137 MDA. The K-40 value has been found to be the highest in Kurşunlu. The Th-232 value has been found to be highest in Fistıklı, which was below the world average value. There is a parallel between Pollution Index, Enrichment Factor and Radioactivity analysis.
\end{abstract}

Keywords: Marmara Sea, Gemlike, elements, radioactive pollution, enrichment factors, Holocene sediment

\section{Introduction}

Industrial development has increased rapidly in the last hundred years and consumption has also risen at the same rate. The increase in consumption has increased the amount of waste and has also caused environmental pollution. With the use of fossil fuels and uncontrolled agriculture (over-application of fertilizer and use of pesticides) the discharge of solid, liquid and gas wastes enter to environment without decontamination, and anthropogenic pollution start to occur in the natural environment.

A specific term for pollution by humans was defined for the first time in 1922 by Alexei Petrovich Pavlov as "anthropogenic pollution" (Bampton, 1999). Toxic matters (heavy metals, natural and artificial radionuclides) derive from anthropogenic pollution sources are significantly dangerous to the environment due to their toxic effects and their accumulation in living things (Omgbu and Kokogbo, 1993).

Gemlik, which is located in the South of the Marmara Region, is one of the developed districts of Bursa with an area of $413 \mathrm{~km}^{2}$ (Koday and Baki, 2014). Gemlik Bay was formed during the late Pliocene-Early Pleistocene on the central branch of the 
North Anatolian Fault (NAF). The gulf is an $11 \times 36 \mathrm{~km}$ pull-apart basin developed in the east-west direction with right lateral strike-slip faults. The deepest part of the gulf is $-113 \mathrm{~m}$, and the gulf forms a closed basin (Ünlü and Alpar, 2006). The area is polluted by many industrial and domestic wastes and is at risk of anthropogenic pollution, as it is a closed basin. In regard to anthropogenic pollution sources, in the vicinity of Gemlik Bay, there is a high density of industry, including manufacturing plants for textiles, metals, refineries, food (olive and olive oil), soap and cement (Alpar et al., 2006). The most important feature of Gemlik Bay which is located on south Marmara shelf is the separation from Marmara pit with a ridge which is $50 \mathrm{~m}$ deep. There are many faults in Gemlik Bay that are compatible with the faults on the land, and some of them control the formation of the bay. Apart from the resources in Gemlik and the Armutlu Peninsula, there are many thermal mineral water sources in the investigated area (Meriç et al., 2005). There are also several ports to the south of the bay. Ports have regional, national and international strategic importance. Various scientific studies have been done in the past years regarding heavy metal and radioactive pollution (Yümün, 2017; Yümün and Önce, 2017; Kam and Önce, 2016; Meriç et al., 2005; Akçay et al., 2003; Okuş et al., 2007; Ünlü and Alpar, 2006). In his study of Yümün (2017), the effect of heavy metal pollution on foraminifera in the Western Marmara Sea (Turkey), is investigated the effects of heavy metals on the foraminiferal assemblages of Holocene deposits in the West Sea of Marmara. The effects of the Quaternary foraminiferal assemblages and heavy metals on foraminifera were investigated by Yümün and Önce (2017). In some stations, shell anomalies were observed in foraminifera, and the chemical, physical, biological and geological environmental conditions as well as heavy metals and biochemical parameters were investigated. Akçay et al. (2003) investigated heavy metal pollution levels in Turkey's economically important Gediz and Büyük Menderes River. Gao and Chen (2012) investigated metal pollution in Bohai Bay in the Bohai Sea. Okuş et al. (2007) stated that Gemlik Bay is polluted by heavy metals and other pollutant groups due to domestic and industrial waste waters. Ünlü and Alpar (2006) investigated the grain-size distribution of Gemlik Bay surface sediments, organic carbon content, heavy metal pollution and PAH distribution. In this study, no significant correlation was observed between total organic carbon content and PAH concentrations. Kam and Önce (2016) determined the heavy metal concentrations in the existing sediments to the southwest of the Marmara Sea.

In this study, heavy metal and radioactive pollution of Gemlik Bay and its surroundings have been investigated. In addition, using the $\mathrm{Fe}, \mathrm{Zn}, \mathrm{As}, \mathrm{Co}, \mathrm{Cu}, \mathrm{Mn}, \mathrm{Ni}$ and $\mathrm{Pb}$ heavy metal concentrations, an enrichment factor (EF) has been calculated. Further, natural and artificial radionuclides have been measured by radiological analyses. Using the measured radionuclides, the natural radioactivity results of Gemlik Bay and its surroundings have been determined. Gemlik Bay is a very active region in terms of industry and ship traffic. In addition, urbanization and tourism facilities are quite high in this region. This study was conducted to draw attention to the effects of heavy metal and radioactivity contamination due to maritime traffic and industry on human environment.

While some of the previous studies (Yümün, 2017; Yümün and Önce, 2017; Meriç et al., 2005; Akçay et al., 2003; Okuş et al., 2007; Ünlü and Alpar, 2006; Gao and Chen, 2012; Omgbu and Kokogbo, 1993; Koday and Baki, 2014; Bampton, 1999) were taken as a reference in terms of method, some studies (Yümün, 2017; Kam and Önce, 2016; Alpar et al., 2006) were taken as reference because they were conducted in the Marmara 
Sea. Previous studies conducted in the Marmara Sea do not include Gemlik-Bandırma Bays. Comparison of the values obtained from previous studies (Heavy metals, radioactivity and foraminifers) with this study aims to compare different regions of the Marmara Sea.

\section{Materials and methods}

In the study, 46 samples have been collected from two boreholes (BH-1 and $\mathrm{BH}-2)$ in 2016 and four Core-Box samples (Core-1, Core-2, Core-3 and Core-4) have been collected from Gemlik Bay in 2019. Drilling samples were taken from boreholes at sea floor to depth by rotary method using hydraulic machines. With the Core-Box method, Core samples were taken with free fall up to a maximum depth of $1 \mathrm{~m}$. All of the core samples and the upper slime and current sediment sections of the drilling samples are discharged at $10 \mathrm{~cm}$ intervals. In order to avoid any difficulties in the sieve analysis of the samples taken, the sample amount is taken between 10-20 grams.

The working area location and sample points are shown in Figure 1 and the sample coordinates are shown in Table 1. For geochemical analysis the samples were first milled. Geochemical analysis of these ground samples for the following elements $(\mathrm{Fe}$, $\mathrm{Zn}, \mathrm{Al}, \mathrm{Mn}, \mathrm{As}, \mathrm{B}, \mathrm{Cd}, \mathrm{Co}, \mathrm{Cr}, \mathrm{Cu}, \mathrm{Ni}, \mathrm{Na}, \mathrm{Mg}, \mathrm{K}, \mathrm{Ca}, \mathrm{P}, \mathrm{Bi}, \mathrm{Mo}, \mathrm{Pb}, \mathrm{Pt}, \mathrm{Sb}, \mathrm{Sn}, \mathrm{Se}$ and $\mathrm{Hg}$ ) was carried out using the SPECTROBLUE model Induced Matched Plasma-Optic Emission Spectrometer (ICP-OES) device at NABILLTEM (Namık Kemal University Central Research Laboratory). In laboratories, the samples are analyzed with ICP-OES devices after being dissolved by the method (king water method, triple acid method, melting method, TS ISO 14869-1, TS ISO 14869-2 etc.) suitable for the analysis to be performed (TSE, 2004a, b).

Table 1. BH and core sample coordinates

\begin{tabular}{|c|c|c|c|c|c|}
\hline \multirow[b]{2}{*}{ Sample No } & \multirow[b]{2}{*}{$\begin{array}{c}\text { The dates of } \\
\text { sample collection }\end{array}$} & \multicolumn{2}{|c|}{ Coordinates } & \multirow{2}{*}{$\begin{array}{l}\text { Water depth } \\
\quad(\mathrm{m})\end{array}$} & \multirow{2}{*}{$\begin{array}{l}\text { Sample size } \\
\text { (m) }\end{array}$} \\
\hline & & $\begin{array}{l}\text { Longitude } \\
\text { (North) }\end{array}$ & $\begin{array}{l}\text { Latitude } \\
\text { (East) }\end{array}$ & & \\
\hline GMK-1 (BH-1) & 10.10 .2016 & $40^{\circ} 27.498^{\prime}$ & $28^{\circ} 58.104^{\prime}$ & 27.00 & 12.80 \\
\hline GMK-2 (BH-2) & 15.0.2016 & $40^{\circ} 27.513^{\prime}$ & $29^{\circ} 5.479^{\prime}$ & 35.60 & 13.30 \\
\hline CORE-1 & 01.05 .2019 & $40^{\circ} 27.888^{\prime}$ & $29^{\circ} 1.797^{\prime}$ & 81.00 & 0.70 \\
\hline CORE-2 & 01.05 .2019 & $40^{\circ} 27.943$ & $28^{\circ} 52.497$ & 75.00 & 1.00 \\
\hline CORE-3 & 01.05 .2019 & $40^{\circ} 22.500^{\prime}$ & $28^{\circ} 59.678^{\prime}$ & 98.00 & 1.00 \\
\hline CORE-4 & 01.05 .2019 & $40^{\circ} 25.769^{\prime}$ & $29^{\circ} 8.317^{\prime}$ & 12.00 & 1.00 \\
\hline
\end{tabular}

The element concentrations obtained by geochemical analysis were evaluated with the Pollution Index (PI) method, and the pollution conditions of the sample locations were obtained. The pollution situation map of Gemlik Bay was prepared by using the PI values and the Kriging Method. Kriging is an advanced geostatistical procedure that generates an estimated surface from a scattered set of points with z-values. The kriging method is a geostatistical method that provides the creation of density maps by statistically evaluating the positions of the measured points in the field. It is a method that quantifies the distances between points by interpolation method in both horizontal and vertical directions. 


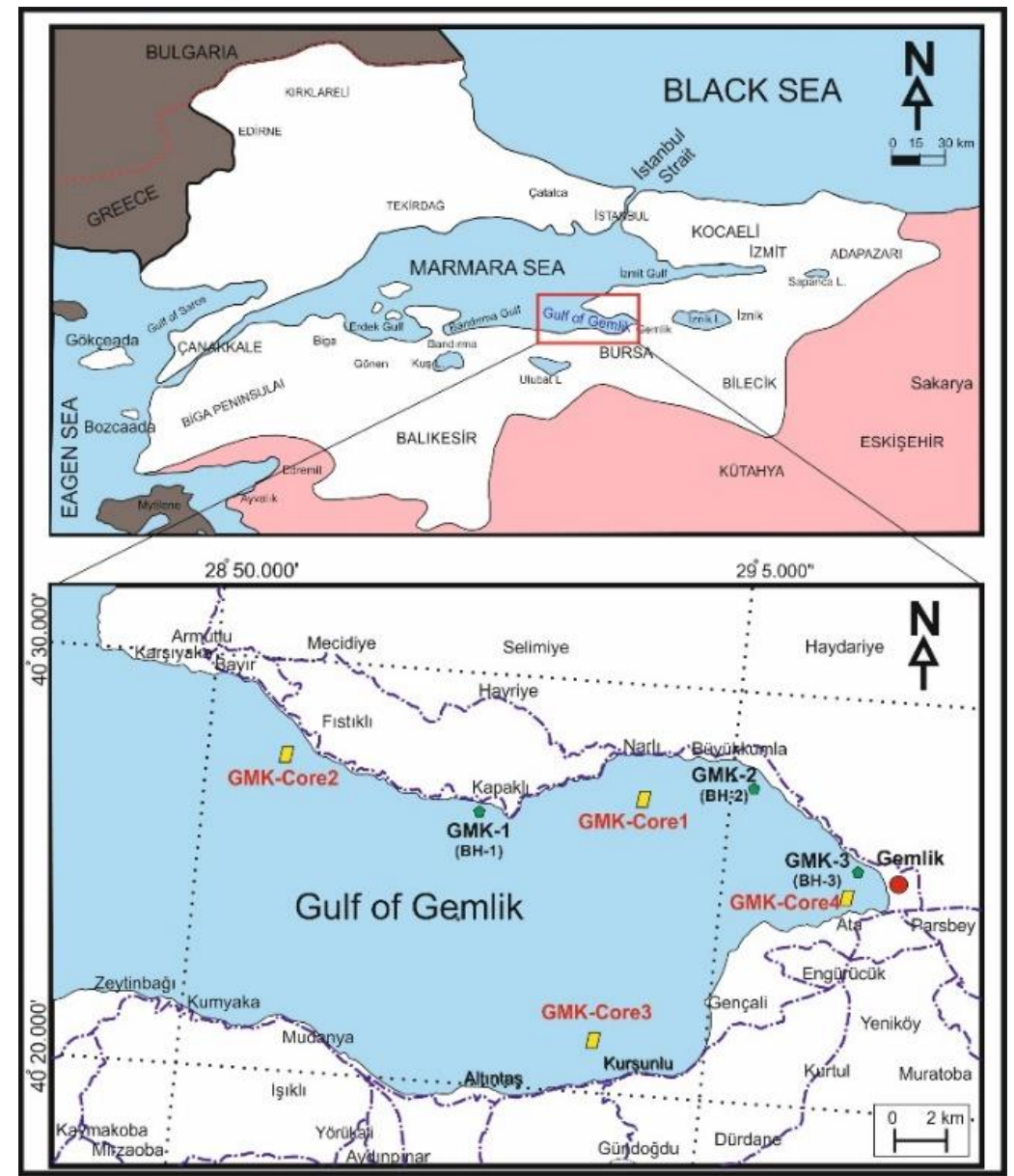

Figure 1. Location map of investigation area

The normalized enrichment factor (EF) was widely used in many studies (BuatMenard, 1979; Hornung et al., 1989; Dickinson et al., 1996; Pekey, 2006) to determine anthropological effects on sediments. In this study, using the results of the heavy metal analysis, the enrichment factor $(\mathrm{EF})$ of the metals ( $\mathrm{Zn}, \mathrm{As}, \mathrm{Co}, \mathrm{Cu}, \mathrm{Ni}, \mathrm{Pb}$ and $\mathrm{Mn}$ ) has been calculated. The enrichment factor is a widely used value in the evaluation of different environments over time and in the calculation of anthropogenic additives in metal pollution (Morillo et al., 2002; Adamo et al., 2005; Valdés et al., 2005). The enrichment factor is calculated by using the following formula:

$$
\mathrm{EF}=(\mathrm{Cn} / \mathrm{Cref}) /(\mathrm{Bn} / \mathrm{Bref})
$$

In this formula, $\mathrm{EF}$ is the enrichment factor, $\mathrm{Cn}$ is the metal value measured in the study, Cref is the value of the working metal in the reference medium (Shell), $\mathrm{Bn}$ is the measured value of the reference element in operation and Bref is the value of the reference element in the reference environment (Shell).

In the calculation and evaluation of this factor, unlike other pollution indices, normalization is performed by selecting a reference element. Although there is no definite acceptance in the selection of the element to be used for normalization, it is generally used in geochemically inactive materials such as aluminium, iron, lithium, zirconium and titanium, which can be easily encountered in fine-grained materials 
(Reinmann et al., 2000; Schiff and Weisberg, 1999; Sutherland, 2000; Ray et. el., 2006; Huerta-Diaz et al., 2008; Essien et al., 2009; Mohiuddin et al., 2010; Zhang et al., 2011; Galuszka et al., 2014; Park et al., 1997; Feng et al., 1998; Baptista Neto et al., 2000; Esen et al., 2008; Taylor et al., 1995).

Within the scope of this study, the element iron has been considered as a reference element due to its lack of large variations in the cores. In addition, natural environmental and artificial radioactivity results of Gemlik Bay and its surroundings have been determined by radionuclide analyses. In this study, ASTM E181- 98 (2003) Standard Test Methods were used for Detector Calibration and Analysis of Radionuclides. For radionuclide analysis, samples have been first prepared for radioactive analysis at room temperature in a laboratory environment.

The radioactivity analyses of the samples were carried out in the TAEK (Technology Development Department Analytical Measurement Unit). Samples were first passed through a 100-micron sieve to a fine powder. The powdered samples were placed in $1000 \mathrm{ml}$ Marinelli flasks and sealed to prevent contact with air. After weighing, the samples were stored for radioactive equilibrium between radium, thorium and other degradation products for 40 days (Yümün and Kam, 2017). Gamma spectrometry analysis of the sediment was performed with a coaxial high purity germanium compound HPGe detector (Canberra GX5020).

\section{Results}

\section{Vertical distribution of sediments in drilling and core samples}

The vertical sections of the drillings (BH-1 and $\mathrm{BH}-2)$ in the study area are given in Figure 2, and the vertical sections of the core samples (Core-1, 2, 3 and 4) are given in Figures 3 and 4 . The samples in the $\mathrm{BH}-1$ are brown-grey, sandy clay, grey-coloured in the middle, sandy-silty clay with high water content and fine, blackish-grey sandy clay at the highest level. The samples in the $\mathrm{BH}-2$ are greenish grey, mollusc shale and claycemented sandy silt and sandy clay, blackish medium sand and silty clay in the middle and blackish-grey, clayey fine sand at the highest level.

The Core-1 section contains dark grey coloured, high water content, fine sandy, silty clay. the Core- 2 section contains dark grey coloured, high water content, fine sandy, sandy clay. The Core-3 section contains grey coloured, high water content, fine sandy, silty clay and the Core-4 section contains dark grey coloured, mollusc shale with interbedded fine sand, sandy clay. Drilling samples were taken during drilling and core samples were obtained from the highest levels of the ground section.

\section{Toxic element analysis of drilling and core samples by geochemical analysis}

Geochemical analysis results for BH-1, BH-2 and core samples are given in Tables 2, 3, 4 and 5. According to the results, $\mathrm{Hg}$ measured $0 \mathrm{ppm}$ at all levels in $\mathrm{BH}-1$ drillings. The concentration values of $\mathrm{Zn}, \mathrm{As}, \mathrm{B}, \mathrm{Cd}, \mathrm{Co}, \mathrm{Cr}, \mathrm{Cu}, \mathrm{Ni} \mathrm{Pb}, \mathrm{Pt}$ and $\mathrm{Sb}$ are between 0 and $300 \mathrm{ppm}$, and these elements are defined as first group elements.

The concentration values of $\mathrm{Na}, \mathrm{Mg}, \mathrm{K}, \mathrm{Ca}, \mathrm{P}, \mathrm{S}, \mathrm{Fe}, \mathrm{Al}$ and $\mathrm{Mn}$ are determined to be $>300 \mathrm{ppm}$, and these elements are evaluated as the second group (Tables 2, 3, 4 and 5). The $300 \mathrm{ppm}$ limit value was used for the first time in this study, and it facilitates the graphical representation of the analysis results. In future studies, taking into account the measurement ranges, it can be taken as a value greater or less than $300 \mathrm{ppm}$. 

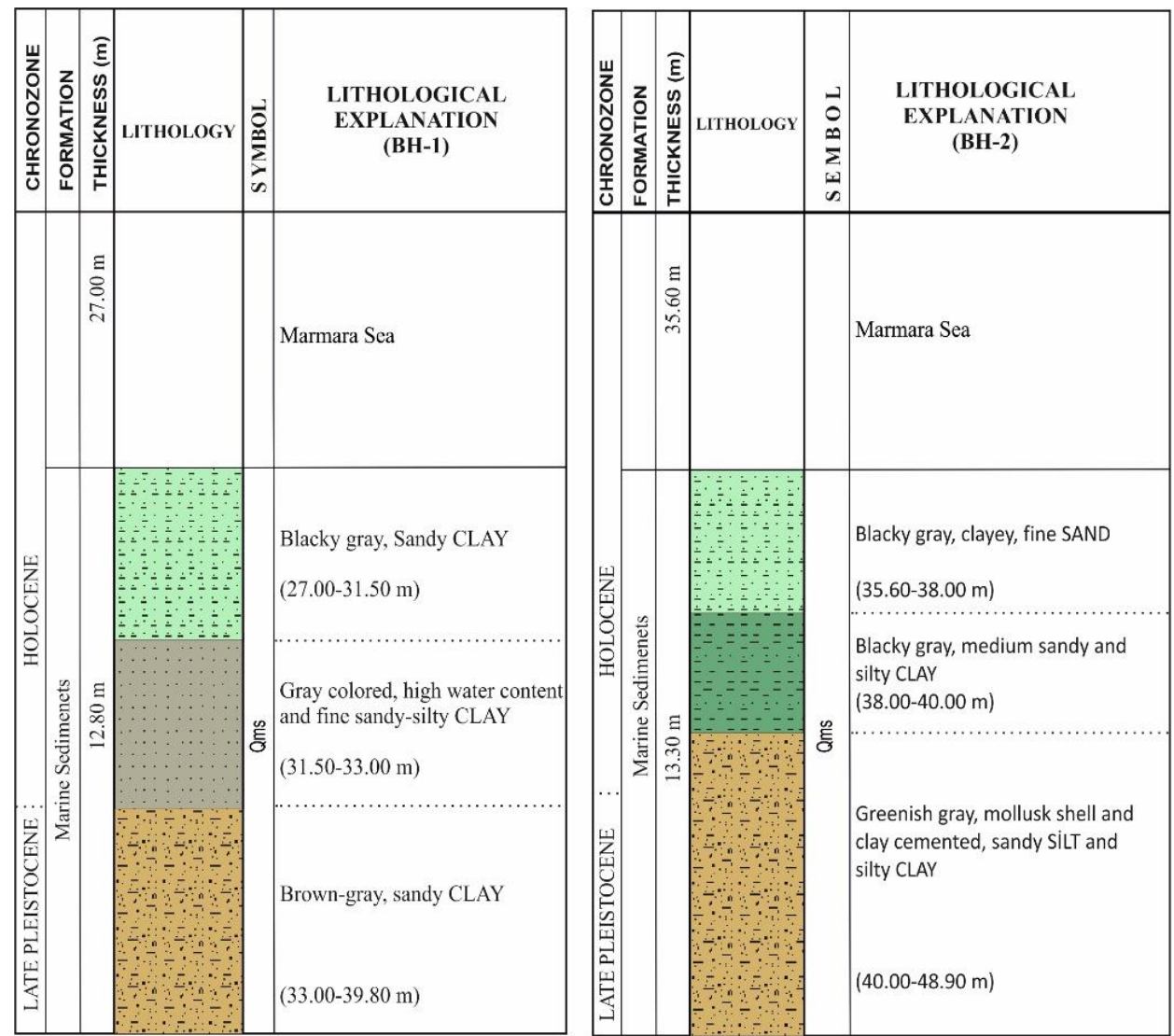

Figure 2. Vertical distribution of current sediments in $\mathrm{BH}-1$ and $\mathrm{BH}-2$ locations

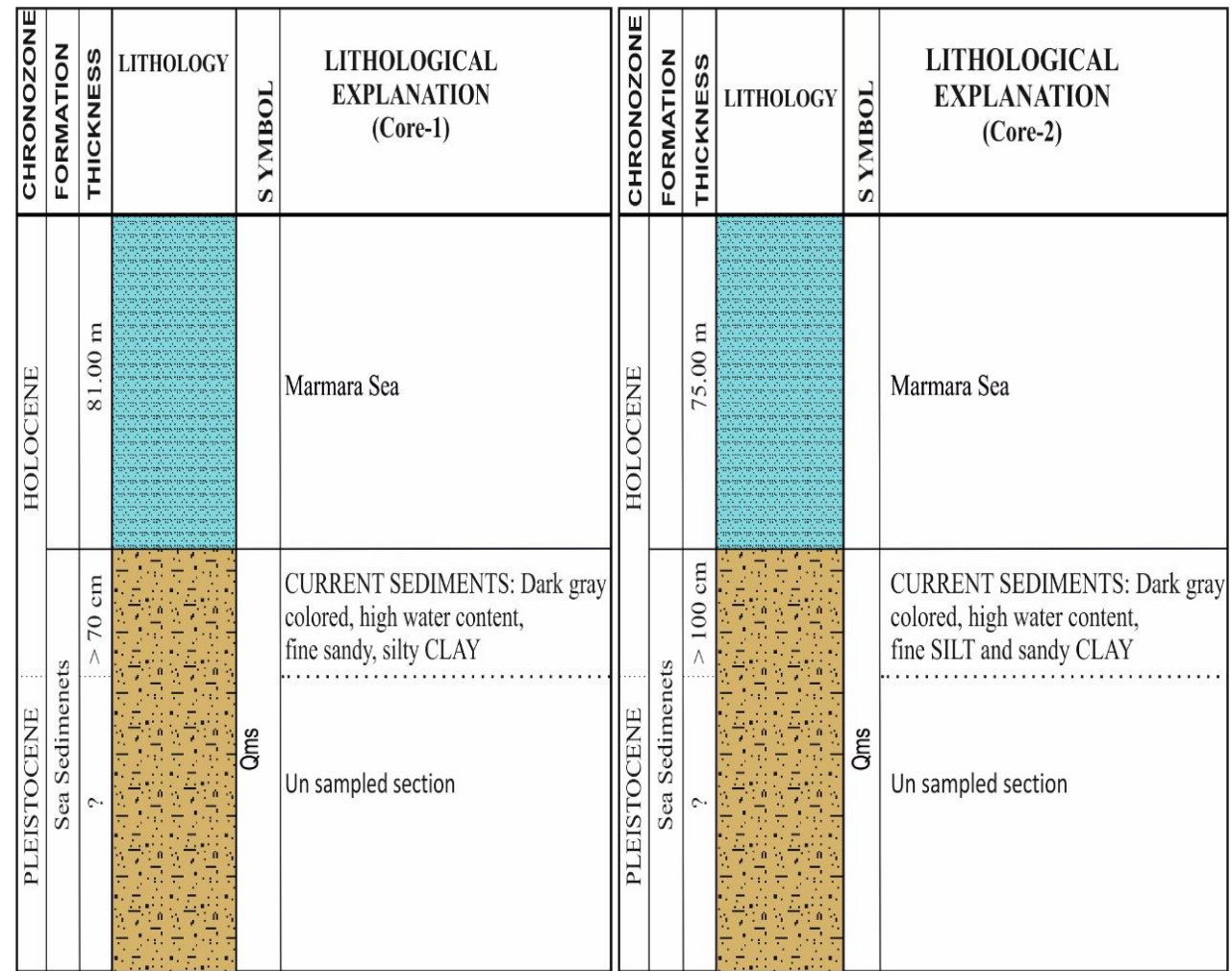

Figure 3. Vertical distribution of current sediments in CORE-1 and CORE-2 locations 


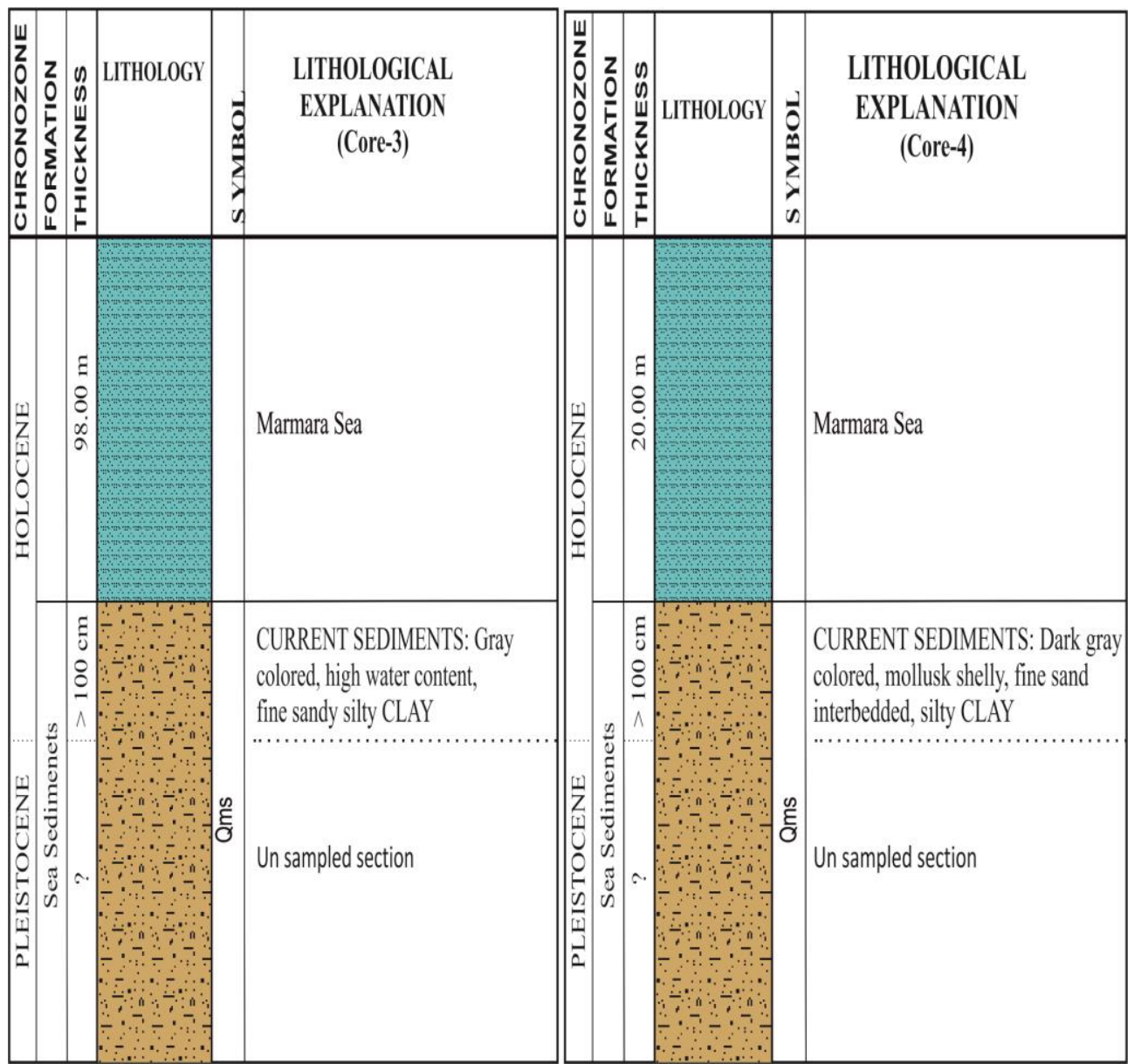

Figure 4. Vertical distribution of current sediments in CORE-3 and CORE-4 locations

There are urban settlements on the shores of the sample locations (locations of drilling and core samples) of the Marmara Sea. This shows that the main responsible for heavy metal pollution are agricultural activities and urban settlements. In the drilling and core sample locations, it was found that the concentrations of the first group elements have been lower in the deep and relatively higher in the surface samples. It was also observed by Yümün (2017) and Yümün and Önce (2018) that the concentrations of some of the first group elements are high at the upper levels of the borehole and relatively lower at the depths. The use of these elements in agricultural fertilizers and pesticides in the current period is seen as a reason for this situation. In addition, it is an important reason for the high level of industrial wastes in the current period.

To evaluate the spatial (horizontal) distribution of the first and second groups of elements, each of the drilling samples was calculated by itself. The mean values of the core samples were calculated separately for each sample. At the concentration values of the second group of elements, there is not much differentiation from the upper level to the lower level of the drilling and cores. As a result, Max./Min./ and average value of firs group elements respectively are (Zn:152.60/74.20/120.10; As: 5.57/0.59/3.23; B: 30.99/12.01/19.63; Cd: 1.71/0.94/1.158; Co: 18.03/5.98/12.9; Cr: 13.28/4.70/8.93; $\mathrm{Cu}: 55.56 / 17.83 / 38.3$; Ni:18.76/7.25/12.6; Pb: 40.33/20.82/32.4; Pt: 1.41/0.51/0.93; Sb: 1.28/0.39/0.91; Hg: 0/0/0) in GMK-1. 
Another result achieved, Max./Min./ and average value of first group elements respectively are GMK-2 (Zn: 96.50/66.70/81.88; As:9.58/1.59/5.067; B:39.40/15.36/30.265; Cd: 2.09/0.81/1.319; Co: 23.94/14.00/19.04; Cr: 97.67/49.43/78.72; $\mathrm{Cu}:$ 65.80/31.66/49.61; $\mathrm{Ni}: 146.12 / 62.29 / 106.11 ; \quad \mathrm{Pb}$ : 11.79/1.66/6.88; Pt: 1.64/0.71/1.054; Sb: 1.89/0.71/1.265; Hg: 0.74/0.00/0.14) in GMK2. As the results of GMK-2 samples, Max./Min./ and average value of second group elements respectively are (Al: 18770.80/8292/ 13978.89; Ca: 10833.60/5071.40/6485.45; $\quad$ Fe: $\quad 34471.90 / 14008.90 / 25790.82 ; \quad \mathrm{K}$ : 3174.80/1223.30/2303.54: Mg: 5981.90/3300.20/4957.90; Mn: 491.60/283.70/386.75; Na: 3998.70/717/2253.48; P: 225.40/108.10/178.62; S: 8473.60/2384.30/4701.51) in GMK-1. Another result achieved, Max./Min./ and average value of second group elements respectively are $(\mathrm{Al}$ : 18884.80/9690.40/15429.49: Ca: 32119.50/5116.40/10300.23; $\quad \mathrm{Fe}: \quad 38680.50 / 25373.90 / \quad 33341.11 ; \quad \mathrm{K}$ : 7493.50/4070.80/5287.81; $\quad \mathrm{Mg}: \quad 12774.10 / 8236.10 / 11278.92 ; \quad \mathrm{Mn}$ : 567.30/290.30/397.93; Na: 8216.80/3803.40/5557.04; P: 433.40/214.50/331.52; S: 5576.20/1434.90/3002.35) in GMK-2.

In addition, the arithmetic mean of each measurement value for each element was calculated (Table 4 and Fig. 5). As a result of these calculations, $\mathrm{Zn}, \mathrm{As}, \mathrm{B}, \mathrm{Cd}, \mathrm{Cr}, \mathrm{Ni}$, $\mathrm{Pt}$ and $\mathrm{Hg}$ values, which are supposed to spread to the environment as a result of agricultural activities, are at the highest levels in Core-1. $\mathrm{Zn}, \mathrm{As}, \mathrm{B}, \mathrm{Cr}, \mathrm{Ni}$ and $\mathrm{Hg}$ values in Core- 2 are higher than the average values. The values of $\mathrm{Zn}, \mathrm{B}, \mathrm{Cd}, \mathrm{Ni}$ and $\mathrm{Pb}$ in the GMK-2 drilling are higher than the average values.

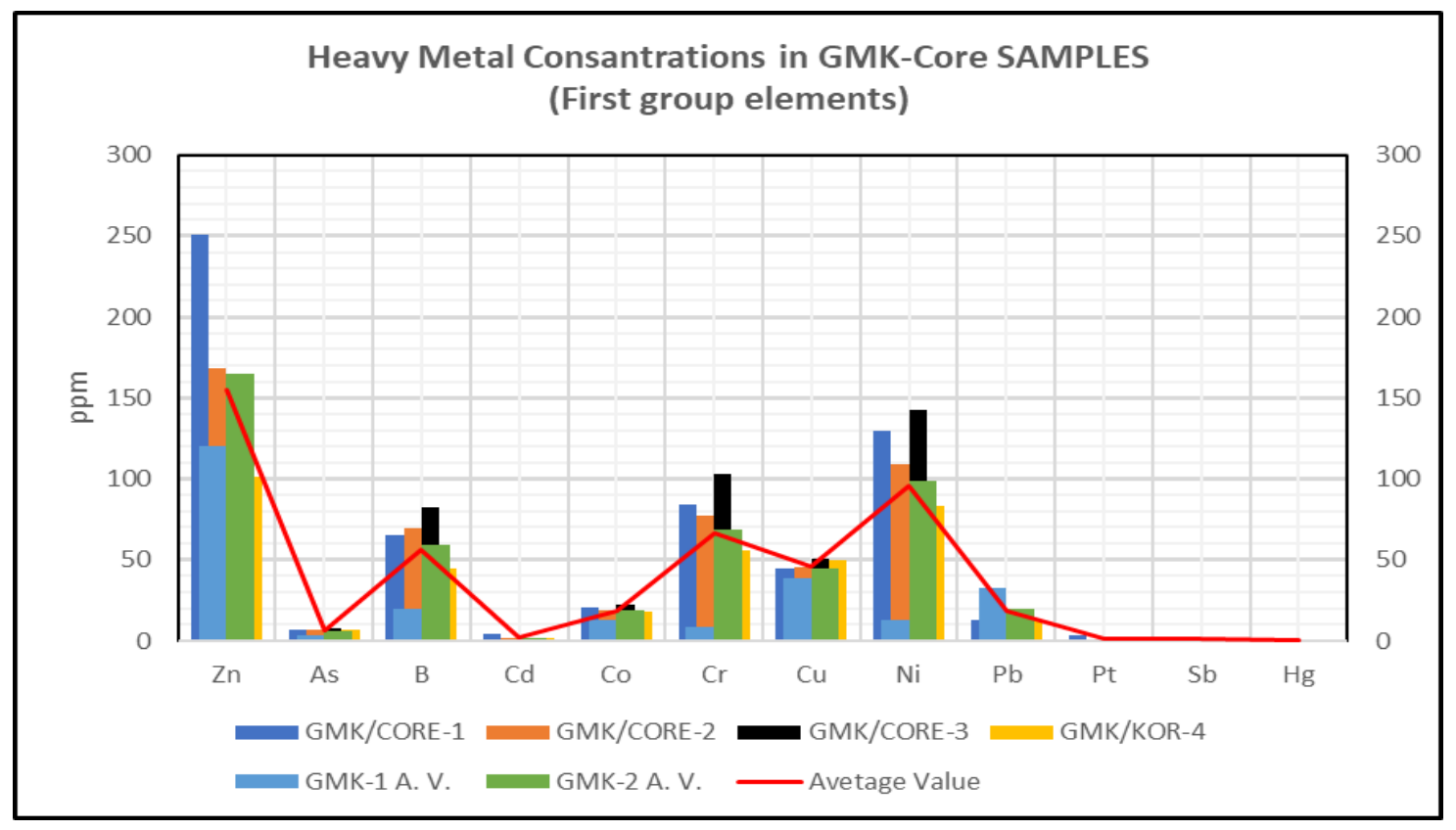

Figure 5. Heavy metal concentrations in GMK-core samples (first group elements)

$\mathrm{Al}, \mathrm{Ca}, \mathrm{Fe}, \mathrm{K}, \mathrm{Mg}, \mathrm{Mn}$ and $\mathrm{P}$ values of the second group are the highest values in the Core-1, Core-2 and Core-3 locations (Table 5 and Fig. 6). In the Core-4 Location, Na, $\mathrm{Mn}$ and $\mathrm{P}$ values are highest. High values in the core locations indicate that the heavy metal density in the current period is higher than those of the previous periods. The average values of the drilling samples represent older periods than today because the 
samples were taken from deeper locations. The fact that the samples representing the current period are rich in heavy metals is an indicator of the presence of mechanisms that pollute the marine environment. Sea transportation in the region and drugs and fertilizers use occurring due to olive cultivation are seen as the main causes of pollution.

Table 2. Geochemical analysis of the first group elements in BH-1 (GMK-1) and BH-2 (GMK-2) drilling

\begin{tabular}{|c|c|c|c|c|c|c|c|c|c|c|c|c|}
\hline \multirow{2}{*}{ Sample No } & $\mathbf{Z n}$ & As & B & Cd & Co & $\mathrm{Cr}$ & $\mathbf{C u}$ & $\mathbf{N i}$ & $\mathbf{P b}$ & $\mathbf{P t}$ & $\mathbf{S b}$ & $\mathrm{Hg}$ \\
\hline & ppm & ppm & ppm & ppm & ppm & ppm & ppm & pm & ppm & ppm & ppm & ppm \\
\hline GMK-1/27-28 & 119.60 & 5.57 & 25.58 & 1.54 & 15.25 & 13.28 & 37.31 & 18.76 & 20.82 & 1.28 & 1.28 & 0.00 \\
\hline GMK-1/28-29 & 8.60 & 3.68 & 18.19 & 0.94 & 8.87 & 7.28 & 21.22 & 9.82 & 27.41 & 0.85 & 0.83 & 0.00 \\
\hline GMK-1/29-30 & 100.90 & 5.29 & 30.99 & 1.06 & 9.70 & 7.05 & 28.39 & 10.56 & 37.06 & 0.97 & 0.81 & 0.00 \\
\hline GMK-1/30-31 & 108.70 & 3.14 & 20.60 & 0.94 & 10.73 & 7.51 & 28.58 & 9.90 & 30.48 & 0.81 & 0.67 & 0.00 \\
\hline GMK-1/31-32 & 29.00 & 4.39 & 23.26 & 1.35 & 15.37 & 10.66 & 42.00 & 13.89 & 33.91 & 0.99 & 0.39 & 0.00 \\
\hline GMK-1/32-33 & 121.90 & 4.28 & 24.17 & 0.96 & 14.23 & 8.09 & 37.86 & 11.98 & 40.33 & 0.75 & 0.97 & 0.00 \\
\hline GMK-1/33-34 & 105.10 & 2.93 & 21.34 & 0.79 & 10.93 & 7.85 & 31.88 & 10.93 & 28.15 & 0.67 & 0.88 & 0.00 \\
\hline GMK-1/34-35 & 74.20 & 2.09 & 20.24 & 0.53 & 5.98 & 4.70 & 17.83 & 7.25 & 24.73 & 0.50 & 0.75 & 0.00 \\
\hline GMK-1/35-36 & 117.40 & 2.28 & 12.01 & 1.19 & 12.41 & 7.21 & 42.06 & 10.97 & 36.66 & 1.12 & 1.24 & 0.00 \\
\hline GMK-1/36-37 & 152.60 & 0.59 & 14.43 & 1.59 & 18.03 & 10.74 & 62.70 & 15.09 & 39.19 & 1.20 & 0.82 & 0.00 \\
\hline GMK-1/37-38 & 139.90 & 2.37 & 14.97 & 1.15 & 14.92 & 9.92 & 48.67 & 14.02 & 36.68 & 0.94 & 0.72 & 0.00 \\
\hline GMK-1/38-39 & 49.30 & 1.82 & 15.31 & 1.71 & 17.70 & 10.98 & 55.56 & 15.65 & 33.53 & 1.41 & 1.26 & 0.00 \\
\hline GMK-1/39-40 & 144.40 & 3.55 & 14.15 & 1.31 & 14.22 & 10.80 & 43.80 & 14.40 & 31.73 & 0.51 & 1.20 & 0.00 \\
\hline $\begin{array}{c}\text { Average value } \\
\text { of BH-1 } \\
\end{array}$ & 120.1 & 3.23 & 19.63 & 1.158 & 12.9 & 8.93 & 38.3 & 12.6 & 32.4 & 0.93 & 0.91 & 0.00 \\
\hline & 6.50 & & & 1.94 & 18.84 & 80.13 & 55.06 & 98.83 & 11.79 & & & 0.74 \\
\hline GMK-2/36-37 & 80.80 & 4.08 & 34.07 & 0.81 & 18.26 & 76.92 & 49.62 & 95.75 & 7.36 & 0.71 & 1.09 & 0.00 \\
\hline GMK-2/37-38 & 73.50 & 3.28 & 28.77 & 1.40 & 17.40 & 66.80 & 44.79 & 87.42 & 1.66 & 0.83 & 1.27 & 0.00 \\
\hline GMK-2/38-39 & 66.70 & 2.39 & 21.36 & 1.10 & 15.26 & 57.81 & 35.50 & 73.50 & 3.60 & 1.00 & 0.89 & 0.00 \\
\hline GMK-2/39-40 & 68.60 & 1.59 & 15.36 & 1.17 & 14.00 & 49.43 & 31.66 & 62.29 & 6.61 & 1.12 & 1.30 & 0.00 \\
\hline GMK-2/40-41 & 74.20 & 2.69 & 21.92 & 1.29 & 17.95 & 79.10 & 46.76 & 98.81 & 7.03 & 0.99 & 1.89 & 0.00 \\
\hline GMK-2/41-42 & 74.10 & 2.22 & 20.88 & 1.43 & 17.76 & 70.27 & 46.73 & 94.99 & 5.62 & 1.30 & 1.35 & 0.00 \\
\hline GMK-2/42-43 & 85.70 & 7.36 & 30.01 & 1.66 & 20.38 & 90.95 & 58.79 & 120.67 & 7.15 & 1.40 & 1.35 & 0.70 \\
\hline GMK-2/43-44 & 80.70 & 6.15 & 37.41 & 0.89 & 18.98 & 75.85 & 50.69 & 101.65 & 5.87 & 0.90 & 1.65 & 0.59 \\
\hline GMK-2/44-45 & 76.50 & 3.49 & 35.52 & 1.34 & 17.62 & 74.22 & 46.96 & 98.22 & 2.31 & 1.09 & 1.39 & 0.00 \\
\hline GMK-2/45-46 & 94.50 & 8.41 & 39.40 & 0.77 & 22.65 & 92.16 & 40.04 & 124.75 & 9.78 & 0.12 & 0.71 & 0.00 \\
\hline GMK-2/46-47 & 89.10 & 6.42 & 37.29 & 1.44 & 21.39 & 92.80 & 60.35 & 134.43 & 9.12 & 1.12 & 1.22 & 0.00 \\
\hline GMK-2/47-48 & 81.10 & 5.78 & 27.60 & 0.83 & 19.71 & 83.69 & 53.13 & 121.77 & 9.27 & 0.82 & 1.38 & 0.00 \\
\hline GMK-2/48-49 & 89.80 & 7.16 & 36.24 & 1.62 & 21.53 & 92.96 & 58.28 & 132.41 & 6.65 & 1.19 & 1.54 & 0.00 \\
\hline GMK-2/49-50 & 96.40 & 9.58 & 31.80 & 2.09 & 23.94 & 97.67 & 65.80 & 146.12 & 9.42 & 1.64 & 1.12 & 0.00 \\
\hline $\begin{array}{c}\text { Average value } \\
\text { of } \mathrm{BH}-2\end{array}$ & 81.88 & 5.067 & 30.265 & 1.319 & 19.04 & 78.72 & 49.61 & 106.11 & 6.88 & 1.054 & 1.265 & 0.14 \\
\hline $\begin{array}{l}\text { Earth crust } \\
\text { (Mason and } \\
\text { Moore, 1982) }\end{array}$ & 70 & 1.8 & & & 25 & - & 55 & 75 & 13 & - & - & \\
\hline
\end{tabular}


Table 3. Geochemical analysis of the second group elements in BH-1 (GMK-1) and BH-2 (GMK-2) drilling

\begin{tabular}{|c|c|c|c|c|c|c|c|c|c|}
\hline \multirow{2}{*}{ Sample No } & Al & $\mathrm{Ca}$ & $\mathrm{Fe}$ & $\mathbf{K}$ & Mg & Mn & $\mathrm{Na}$ & $\mathbf{P}$ & $\mathbf{S}$ \\
\hline & ppm & ppm & ppm & ppm & ppm & ppm & ppm & ppm & ppm \\
\hline MK-1/27-28 & 14956.60 & 9122.70 & 28954.60 & 2747.10 & 5700.60 & 419.40 & 3998.70 & 210.70 & 3382.80 \\
\hline & 406.10 & 94.10 & 20531.10 & 99.10 & 4048.90 & 326.60 & 2605.80 & 46.80 & 3786.80 \\
\hline GMK-1/29-30 & 1701.20 & 5615.70 & 22252.60 & & 4346.00 & & 3259.90 & & \\
\hline & 13214.00 & 5071.40 & 23189.70 & 7.60 & 425 & & 90 & 160.60 & \\
\hline & & 532 & & & 598 & & & & \\
\hline iMK-1/32-33 & 14658.60 & 5840.30 & 25922.40 & 2326.50 & 5272.70 & 377.20 & 2987.80 & 185.60 & \\
\hline GMK-1/33-34 & 12124.70 & 10833.60 & 21336.30 & 2080.30 & 4733.70 & & & & \\
\hline & 8292.00 & 5761.10 & 14008. & 122 & 330 & 28 & & & \\
\hline & 11580 & 4812 & 24439 & & & & & & \\
\hline MK-1/36-37 & 18770.80 & 5268.20 & 34471 & & & 45 & & & \\
\hline 38 & 15727.40 & 5301.40 & 28463. & & 530 & & 150 & 201.00 & \\
\hline & 17620.50 & 6191.10 & 32291 & & & & & & \\
\hline MK-1/39-40 & 14183.30 & 9069.10 & 29240.20 & .60 & 5568 & 419. & & 165.80 & \\
\hline $\begin{array}{c}\text { Average } \\
\text { value of } \mathrm{BH}-1\end{array}$ & 13978.89 & 6485.45 & 25790.82 & 2303.45 & 4957.90 & 386.75 & & 178.62 & \\
\hline GMK-2/35-36 & 17169.60 & 10304. & & 589.30 & 11915.10 & & & 359.50 & \\
\hline 7 & 15420.50 & $1049^{\circ}$ & 321 & & & & & 327.30 & \\
\hline & 13726.40 & 9507.50 & 31460.80 & .00 & 1019 & 342 & & 307.20 & \\
\hline GMK-2/38-39 & 12133.60 & 6007.20 & 27949. & 3812.40 & 9319.00 & 380 & 4067 & 205.00 & 483 \\
\hline & & 5204.20 & 25373. & & 8236.10 & 290. & 380 & 214.50 & \\
\hline GMK-2/40-41 & 13146.80 & 7332.20 & 31076.80 & 4070.80 & 10341.90 & 375.70 & 3965.80 & 271.30 & 1666 \\
\hline GMK-2/41-42 & 12071.30 & 7494.80 & 30204.50 & 3662.30 & 10349.80 & 364.40 & 4181.10 & 262.50 & 1758 \\
\hline GMK-2/42-43 & 15307.30 & 7442.70 & 35929.80 & 4929.40 & 12081.30 & & 5297.50 & 315.80 & 4463 \\
\hline & 15440.50 & 16867 & 334 & & 10992 & 415 & & 574.60 & 5002 \\
\hline GMK-2/44-45 & 14580.80 & 14639.20 & 31457.20 & 5095.80 & 10944.60 & 352. & 5658.50 & 298.80 & 4582.80 \\
\hline GMK-2/45-46 & 21749.60 & 32119.50 & 40377.10 & 6390.50 & 15475.20 & 505.40 & 6893.60 & 433.40 & 5576.20 \\
\hline & 18108. & 7598.70 & 36051.30 & 7493.50 & 12651. & & & & \\
\hline GMK-2/47-48 & 15421.10 & 6170.80 & 32852.10 & 4972.40 & 10968.30 & 369.30 & 5215.10 & 296.80 & 2884.80 \\
\hline GMK-2/48-49 & 18884.80 & 8200.60 & 37363.60 & 7359.90 & 12774.10 & 446.70 & 6810.90 & 360.40 & 2112.20 \\
\hline GMK-2/49-50 & 18590.90 & 5116.40 & 38680.50 & 6258.60 & 12266.20 & 567.30 & 5704.60 & 409.60 & 1434.90 \\
\hline alue of BH-2 & & 10500.22 & 33341.11 & & 11278.92 & 397.93 & 5557.04 & 331.52 & \\
\hline
\end{tabular}

Table 4. Mean values of Group 1 elements in drilling and core samples

\begin{tabular}{c|c|c|c|c|c|c|c|c|c|c|c|c}
\hline Sample No & $\mathbf{Z n}$ & $\mathbf{A s}$ & $\mathbf{B}$ & $\mathbf{C d}$ & $\mathbf{C o}$ & $\mathbf{C r}$ & $\mathbf{C u}$ & $\mathbf{N i}$ & $\mathbf{P b}$ & $\mathbf{P t}$ & $\mathbf{S b}$ & $\mathbf{H g}$ \\
\hline GMK/CORE-1 & 250.90 & 6.66 & 65.04 & 3.98 & 20.74 & 84.28 & 45 & 129.45 & 13.26 & 3.49 & 1.60 & 0.61 \\
GMK/CORE-2 & 168.50 & 7.13 & 69.54 & 1.58 & 18.8 & 77.27 & 45.62 & 109.16 & 16.34 & 1.14 & 1.38 & 0.65 \\
GMK/CORE-3 & 121.50 & 7.76 & 82.14 & 0.57 & 22.32 & 103.18 & 50.6 & 142.67 & 16.88 & 0 & 1.77 & 0.00 \\
GMK/CORE-4 & 101.30 & 6.48 & 44.60 & 1.64 & 18.38 & 55.82 & 49.49 & 83.46 & 11.73 & 1.19 & 1.02 & 0.00 \\
GMK-1 A. V. & 120.10 & 3.23 & 19.63 & 1.158 & 12.9 & 8.93 & 38.3 & 12.6 & 32.4 & 0.93 & 0.91 & 0.00 \\
GMK-2 A. V. & 165.25 & 6.19 & 59.088 & 1.822 & 18.69 & 68.42 & 44.88 & 98.47 & 19.72 & 1.39 & 1.42 & 0.135 \\
\hline $\begin{array}{c}\text { Average value } \\
\text { of Gulf of } \\
\text { Gemlik }\end{array}$ & $\mathbf{1 5 4 . 5 9}$ & $\mathbf{6 . 2 4}$ & $\mathbf{5 6 . 6 7}$ & $\mathbf{1 . 7 9}$ & $\mathbf{1 8 . 6 4}$ & $\mathbf{6 6 . 3 1 7}$ & $\mathbf{4 5 . 6 4 8}$ & $\mathbf{9 5 . 9 7}$ & $\mathbf{1 8 . 3 9}$ & $\mathbf{1 . 3 6}$ & $\mathbf{1 . 3 5}$ & $\mathbf{0 . 2 3 3}$ \\
\hline
\end{tabular}


Table 5. Mean values of group-2 elements in drilling and core samples

\begin{tabular}{c|c|c|c|c|c|c|c|c|c}
\hline Sample No & Al & Ca & Fe & K & Mg & Mn & Na & P & S \\
\hline Core-1 & 20103.60 & 23893.70 & 37460.90 & 11050.20 & 15491.70 & 954.20 & 16492.80 & 365.20 & 3113.90 \\
Core-2 & 18861.40 & 28558.60 & 34994.70 & 10293.50 & 14441.30 & 561.80 & 16654.70 & 322.80 & 5744.20 \\
Core-3 & 21236.90 & 27808.30 & 39166.50 & 13499.10 & 16654.90 & 817.70 & 19783.30 & 418.60 & 3247.40 \\
GMK/CORE-4 & 7644.80 & 11144.10 & 7754.30 & 22947.00 & 538.40 & 2637.90 & 35132.30 & 18475.20 & 450.50 \\
GMK-1 A. V. & 13978.89 & 6485.446 & 25790.82 & 2303.45 & 4957.90 & 386.7462 & 2253.49 & 178.62 & 4701.51 \\
GMK-2 A. V. & 15429.49 & 10300.23 & 33341.11 & 5287.81 & 11278.92 & 397.9267 & 5557.04 & 331.52 & 3002.35 \\
\hline $\begin{array}{c}\text { Average value } \\
\text { of Gulf of } \\
\text { Gemlik }\end{array}$ & 17922.06 & 19409.26 & 34150.81 & 8486.81 & 12564.94 & 623.67 & 12148.27 & 323.35 & 3961.87 \\
\hline
\end{tabular}

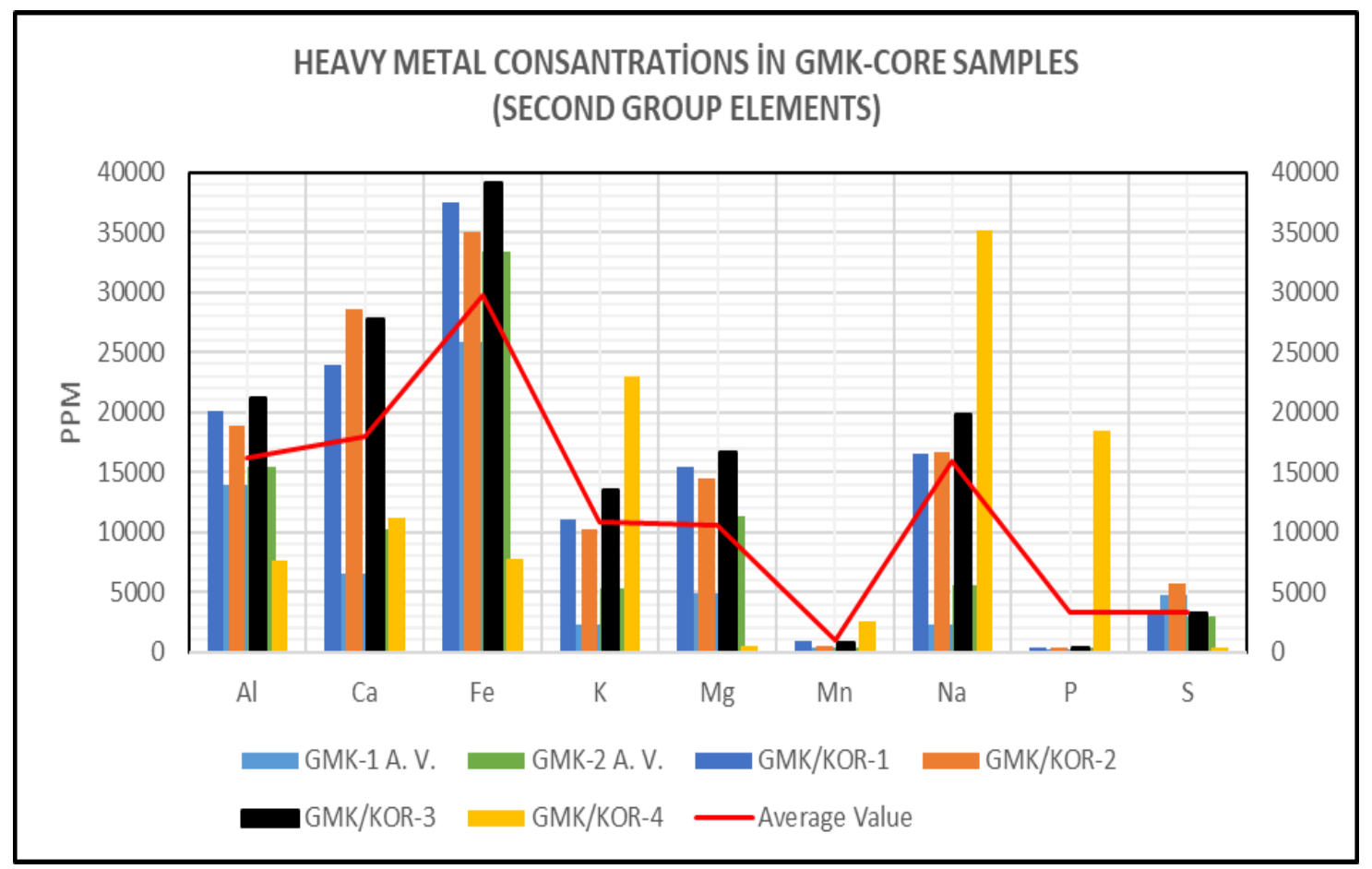

Figure 6. Mean values of group 2 elements in drilling and core samples

\section{Evaluation of the pollution of Gemlike Bay with analysis of the pollution index (PI)}

An average value, defined as a Pollution Index (PI), was first described by Yümün (2017) in order to simplify the results of geochemical analysis of all core and drilling samples taken from the western part of the Sea of Marmara. This method, which is also considered by many researchers, is used in this study. In the pollution index calculations, the geochemical analysis results of the sediments from the East Marmara Sea have been used. The calculations were performed by dividing the individual totals of the heavy metal measurement values to the total average value by the number of measurements (Table 6). In this study, a pollution-zone map was created by the Kriging method to visually evaluate the pollution analysis of Gemlik Bay (Fig. 7).

It is seen that PI $>1$ in the vicinities of Narlı (Gemlik-Bursa) and Büyükkumla (Gemlik-Bursa) and Kurşunlu, Gemlik Fıstıklı and Kumyaka in the pollution-zone map; 
these values are above the threshold of dangerous in terms of pollution. The pollution between Kumkaya, Fıstıklı and Narlı (Gemlik-Bursa) and Büyükkumla (Gemlik-Bursa) is thought to be caused by agricultural activities and ship traffic. The pollution values of Gemlik and Kursunlu are caused by industrial wastes and ship traffic.

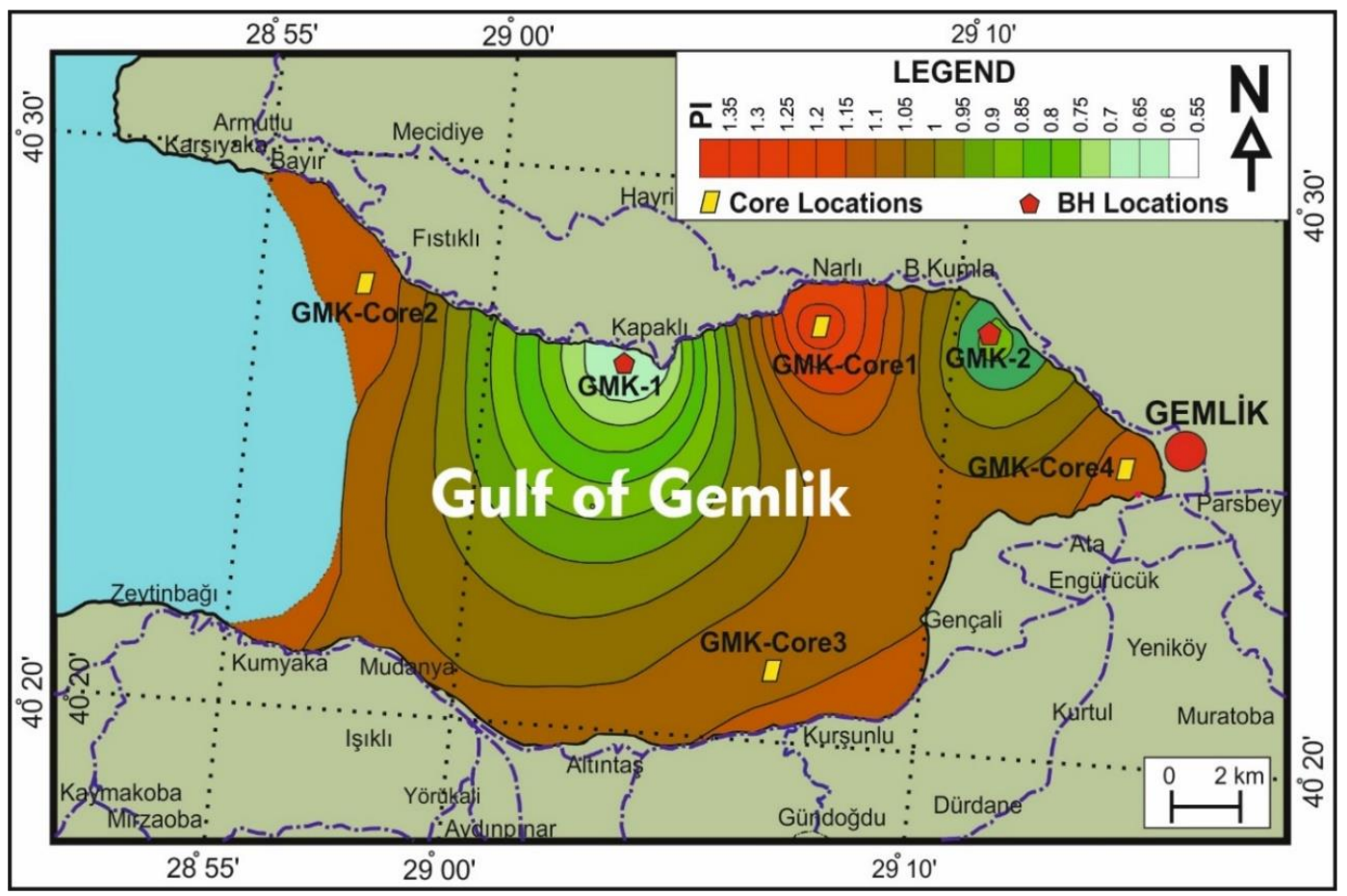

Figure 7. Pollution-zone map generated by the Kriging method to PI values

Table 6. Gemlik Bay pollution index (PI) values

\begin{tabular}{c|c|c|c}
\hline Sample No & Y & X & PI \\
\hline CORE-1 & 672101.00 & 4481326.00 & 1.325 \\
CORE-2 & 658957.00 & 4481138.00 & 1.146 \\
CORE-3 & 669332.26 & 4471289.20 & 1.086 \\
CORE-4 & 681410.00 & 4477624.00 & 1.124 \\
GMK-1 A. V. & 666899.00 & 4480487.00 & 0.5739 \\
GMK-2 A. V. & 677320.00 & 4480755.00 & 0.8691 \\
\hline
\end{tabular}

\section{Radiological analysis of $\mathrm{BH}$ and core samples}

The results of radiological measurements of the sediment samples obtained from the sampling locations are given in Table 7. At the same time significant natural radionuclides in soil and their world average specific activities are given in Table 8. According to the measurement results, Ra-226 has been found below the world average value in all locations. The K-40 values are above the world average values in the $\mathrm{BH}-1$ sounding are from the intensive agricultural activities in that part of the study area. In the BH-2 drilling, K-40 values are below average. Th-232 values have been found to be below the world average value (30 Bq/kg) in $\mathrm{BH}-1$ and $\mathrm{BH}-2$ drillings except for $\mathrm{BH}-2 / 3$ (the highest value in $\mathrm{BH}-2 / 3(39.85 \mathrm{~Bq} / \mathrm{kg})$ ). The Cs-137 values have reached the highest 
value by exceeding $5.3 \mathrm{~Bq} / \mathrm{kg}$ in $\mathrm{BH}-1 / 1$ drilling. The high Cs-137 in this area draws attention to the presence of artificial radioactivity. In all other locations, Cs-137 is below the background level. According to these results, the study area has not contained any unnatural radioactivity except $\mathrm{BH}-1 / 1$. In addition, the measurement of the high Cs-137 value in the top layer of drilling is an indication of anthropogenic pollution. In the core samples, the K-40 value was determined to be the highest $(498 \mathrm{~Bq} / \mathrm{kg}$ ) in Kurşunlu, and this value was above the world average value. Th-232 was found to be the highest in Fistikl1 (42.82 Bq/kg), and this value is above the world average value. Ra-226 has also been found to be the highest in Fist1kl1, but this value has been below the world average value. Cs-137 is below the background level in all core samples. When the results are examined, it is seen that natural and artificial radionuclides increase in sediment as an effect of anthropogenic pollution in the study area.

Table 7. Radiological measurement results of GMK-1 (BH-1), GMK-2 (BH-2) Core-1, Core-

2 and Core-3 (background is natural value of radionuclides of rocks)

\begin{tabular}{c|c|c|c|c}
\hline Sample No & $\begin{array}{c}\text { K-40 } \\
(\mathbf{B q} / \mathbf{k g})\end{array}$ & $\begin{array}{c}\mathbf{T h}-\mathbf{2 3 2} \\
\mathbf{( B q} / \mathbf{k g})\end{array}$ & $\begin{array}{c}\mathbf{R a - 2 2 6} \\
\mathbf{( B q} / \mathbf{k g})\end{array}$ & $\begin{array}{c}\text { Cs-137 } \\
\mathbf{( B q} / \mathbf{k g})\end{array}$ \\
\hline GMK-1/1 & $\mathbf{8 5 3} \pm \mathbf{2 9 . 2 1}$ & Background & Background & $\mathbf{5 . 3} \pm \mathbf{2 9 . 2 1}$ \\
GMK-1/2 & $\mathbf{4 9 7} \pm \mathbf{2 2 . 2 9}$ & Background & $23.24 \pm 4.80$ & Background \\
GMK-1/3 & $\mathbf{5 3 0} \pm \mathbf{2 3 . 0 2}$ & $25.87 \pm 5.7$ & $17.91 \pm 4.12$ & Background \\
GMK-2/1 & $82.42 \pm 9.06$ & Background & Background & Background \\
GMK-2/2 & $143.45 \pm 11.95$ & $7.63 \pm 2.65$ & $8.91 \pm 2.82$ & Background \\
GMK-2/3 & $\mathbf{5 9 5} \pm \mathbf{2 4 . 3 9}$ & $\mathbf{3 9 . 8 5} \pm \mathbf{6 . 2 4}$ & $25.34 \pm 5.03$ & Background \\
CORE-1 & $396 \pm 19.89$ & Background & $\mathbf{3 9 . 8 5} \pm \mathbf{6 . 2 4}$ & Background \\
CORE-2 & $359 \pm 18.94$ & $\mathbf{4 2 . 8 2} \pm \mathbf{6 . 5 4}$ & $28.51 \pm 5.30$ & Background \\
CORE-3 & $\mathbf{4 9 8} \pm \mathbf{2 2 . 3 1}$ & $\mathbf{3 6 . 5 8} \pm \mathbf{6 . 0 5}$ & $\mathbf{3 9 . 8 5} \pm \mathbf{6 . 2 4}$ & Background \\
\hline
\end{tabular}

Table 8. Significant natural radionuclides in soil and their world average specific activities (UNSCEAR, 2000) (MDA is measurement value that is less than detection limits of measurement tools)

\begin{tabular}{|c|c|c|c|c|c|}
\hline \multirow[b]{2}{*}{ Radionuclide $^{a}$} & \multicolumn{2}{|c|}{$\begin{array}{c}\text { Concentration in soil } \\
\left(\mathrm{Bq} \mathrm{kg} \mathbf{~ k}^{-1}\right)\end{array}$} & \multirow{2}{*}{$\begin{array}{c}\text { Dose coefficient } \\
{[\text { II20, S49] }} \\
\left(\text { nGy h-1 per Bq kg } \text { kg }^{-1}\right)\end{array}$} & \multicolumn{2}{|c|}{$\begin{array}{c}\text { Absorbed dose rate in air } \\
\left(\mathrm{nGy} \mathrm{h}^{-1}\right)\end{array}$} \\
\hline & Median value ${ }^{\mathrm{a}}$ & $\begin{array}{l}\text { Population- } \\
\text { weighted }^{\text {value }} \\
\text { a }\end{array}$ & & Median value & $\begin{array}{c}\text { Population- } \\
\text { weighted value }\end{array}$ \\
\hline $40_{K}$ & 400 & 420 & 0.0417 & 17 & 18 \\
\hline${ }^{228} \mathrm{U}$ series & 35 & 33 & 0.462 & 16 & 15 \\
\hline${ }^{232} \mathrm{Th}$ series & 30 & 45 & 0.604 & 18 & 27 \\
\hline Cesium-137 & $<\mathrm{MDA}=2.1$ & & & & \\
\hline Total & & & & 51 & 60 \\
\hline
\end{tabular}

${ }^{a}$ Values from Table 5 (UNSCEAR, 2000)

Radionuclide values were taken from 43 countries from 7 continents (Africa, North America, East Asia, West Asia, West Europe, East Europe, and South Europe) to represent world averages (UNSCEAR, 2000). In the study conducted by UNSCEAR (2000), 
arithmetic averages of the radionuclide values obtained from 43 countries were accepted as the average natural radionuclide content of the soils for the whole world (Table 8).

\section{Enrichment factor results for Gemlik Bay}

Natural soil values and the enrichment factor values calculated for Gemlik Bay are given in Tables 9, 10 and 11. According to the results of the enrichment factors, EFNi has found to be between 3-5 and other EF values have been lower than 3. The fact that EFNi is between 3-5 indicates that $\mathrm{Ni}$ is becoming enriched in the region. Specifically, the enrichment of $\mathrm{Ni}$ shows that the drainage waters of agricultural origin pollute the area. The calculated EF value, being close to 1, indicates the earth's crust, while its value between 3-5 indicates the earth's crust. And EF value greater than 5 indicates that the enrichment is not of crustal origin (Galuszka et al., 2014; Halstead et al., 2000; Mason and Moore, 1982).

Table 9. Enrichment factor calculations of $\mathrm{BH}-1$ drilling

\begin{tabular}{c|c|c|c|c|c|c|c}
\hline Sample No & EF ZN & EF AS & EF CO & EF CU & EF NI & EF PB & EF MN \\
\hline GMK-1/27-28 & 0.34 & 0.02 & 0.95 & 0.85 & $\mathbf{2 . 3 2}$ & 0.36 & 0.68 \\
GMK-1/28-29 & 0.29 & 0.04 & $\mathbf{1 . 1 6}$ & $\mathbf{1 . 0 6}$ & $\mathbf{3 . 1 4}$ & 0.19 & 0.61 \\
GMK-1/29-30 & 0.31 & 0.06 & $\mathbf{1 . 1 5}$ & 0.86 & $\mathbf{3 . 1 6}$ & 0.16 & 0.64 \\
GMK-1/30-31 & 0.3 & 0.06 & $\mathbf{1 . 0 8}$ & 0.89 & $\mathbf{3 . 5 1}$ & 0.2 & 0.67 \\
GMK-1/31-32 & 0.33 & 0.03 & 0.98 & 0.79 & $\mathbf{3 . 2 6}$ & 0.23 & 0.87 \\
GMK-1/32-33 & 0.3 & 0.05 & 0.91 & 0.75 & $\mathbf{3 . 2 4}$ & 0.17 & 0.74 \\
GMK-1/33-34 & 0.28 & 0.06 & 0.98 & 0.74 & $\mathbf{2 . 9 3}$ & 0.2 & 0.64 \\
GMK-1/34-35 & 0.26 & 0.11 & 1.17 & 0.86 & $\mathbf{2 . 9}$ & 0.15 & 0.56 \\
GMK-1/35-36 & 0.29 & 0.08 & 0.98 & 0.64 & $\mathbf{3 . 3 4}$ & 0.17 & 0.59 \\
GMK-1/36-37 & 0.32 & 0.15 & 0.96 & 0.6 & $\mathbf{3 . 4 3}$ & 0.23 & 0.78 \\
GMK-1/37-38 & 0.28 & 0.05 & 0.95 & 0.64 & $\mathbf{3 . 0 4}$ & 0.2 & 0.75 \\
GMK-1/38-39 & 0.3 & 0.08 & 0.91 & 0.64 & $\mathbf{3 . 0 9}$ & 0.25 & 0.68 \\
GMK-1/39-40 & 0.28 & 0.05 & 1.03 & 0.73 & $\mathbf{3 . 0 5}$ & 0.24 & 0.64 \\
Average & $\mathbf{0 . 2 9}$ & $\mathbf{0 . 0 6}$ & $\mathbf{1 . 0 1}$ & $\mathbf{0 . 7 7}$ & $\mathbf{3 . 1 0}$ & $\mathbf{0 . 2 1}$ & $\mathbf{0 . 6 8}$ \\
EF analysis & EF Zn $<1$ & EFAs $<1$ & EFCo $\leq 1$ & EFCu $<1$ & $3<$ EFNi $<5$ & EFPb $<1$ & EFMn $<1$ \\
\hline
\end{tabular}

\section{Discussion}

With the geochemical analysis performed by ICP-OES method, toxic element concentration distributions were calculated and pollution analysis of the study area was made. The concentration distributions obtained were analyzed with the Pollution Index (PI) method defined by Yümün (2017). According to the PI results, it has been observed that the pollution is high especially in port areas with heavy ship traffic. The ship traffic in the Narl1, Gemlik and Kurşunlu parts of the Marmara Sea is also seen in the high Figure 8. It is seen that PI and Enrichment Factors (EFCo, EFCu, EFPb) are also high in areas with high ship traffic. The Map of Waterways in the Sea of Marmara given in Figure 8 has been examined to determine whether the areas with high marine pollution have a relationship with sea traffic (http://apelasyon.com/Yazi/536-deniz-yollari). The highly polluted areas determined in the PI map, the areas with high values in the Enrichment Factor calculations exactly overlap with the heavy traffic areas seen in the Sea Waterways map given in Figure 8. 


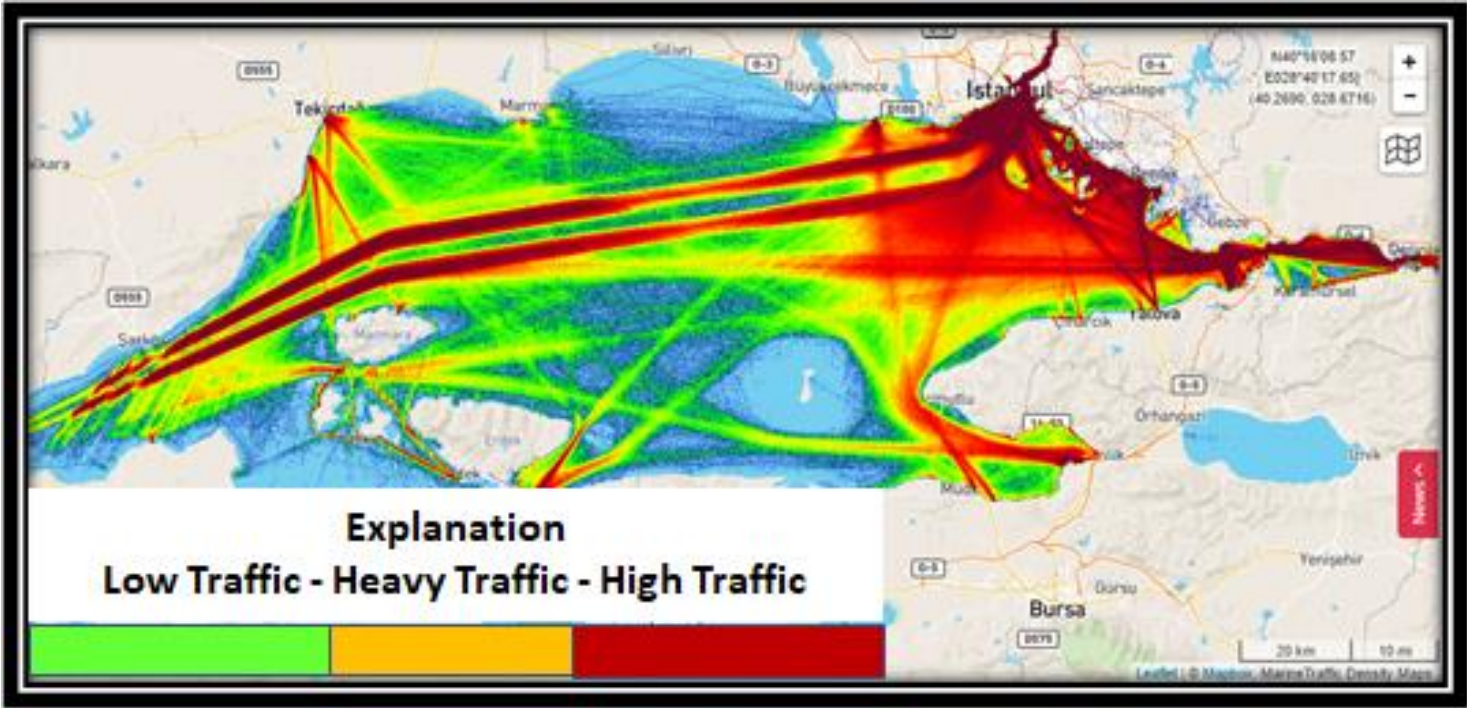

Figure 8. Waterways of the Marmara Sea (marine traffic) (http://apelasyon.com/Yazi/536deniz-yollari)

Table 10. Enrichment factor calculations of BH-2 drilling

\begin{tabular}{c|c|c|c|c|c|c|c}
\hline & EF ZN & EF AS & EF CO & EF CU & EF NI & EF PB & EF MN \\
\hline GMK-2/35-36 & 0.52 & 0.02 & 0.95 & 0.71 & 0.54 & 0.79 & 0.9 \\
GMK-2/36-37 & 0.56 & 0.02 & 0.88 & 0.71 & 0.5 & $\mathbf{1 . 1 3}$ & 0.83 \\
GMK-2/37-38 & 0.6 & 0.03 & 0.9 & 0.77 & 0.54 & $\mathbf{4 . 9 2}$ & 0.76 \\
GMK-2/38-39 & 0.59 & 0.07 & 0.92 & 0.87 & 0.57 & $\mathbf{2 . 0 2}$ & 0.61 \\
GMK-2/39-40 & 0.52 & 0.04 & 0.91 & 0.88 & 0.61 & 1 & 0.63 \\
GMK-2/40-41 & 0.59 & 0.02 & 0.87 & 0.73 & 0.47 & 1.15 & 0.66 \\
GMK-2/41-42 & 0.57 & 0.03 & 0.85 & 0.71 & 0.48 & 1.4 & 0.63 \\
GMK-2/42-43 & 0.59 & 0.02 & 0.88 & 0.67 & 0.45 & 1.31 & 0.67 \\
GMK-2/43-44 & 0.58 & 0.03 & 0.88 & 0.73 & 0.49 & 1.48 & 0.71 \\
GMK-2/44-45 & 0.58 & 0.05 & 0.89 & 0.74 & 0.48 & 3.54 & 0.79 \\
GMK-2/45-46 & 0.6 & 0.02 & 0.89 & 1.11 & 0.49 & 1.07 & 0.82 \\
GMK-2/46-47 & 0.57 & 0.01 & 0.84 & 0.66 & 0.4 & 1.03 & 0.84 \\
GMK-2/47-48 & 0.57 & 0.02 & 0.83 & 0.68 & 0.4 & 0.92 & 0.79 \\
GMK-2/48-49 & 0.58 & 0.01 & 0.87 & 0.71 & 0.42 & 1.46 & 0.8 \\
GMK-2/49-50 & 0.56 & 0.01 & 0.81 & 0.65 & 0.4 & 1.07 & 0.62 \\
Average & $\mathbf{0 . 5 7}$ & $\mathbf{0 . 0 3}$ & $\mathbf{0 . 8 7}$ & $\mathbf{0 . 7 6}$ & $\mathbf{0 . 4 8}$ & $\mathbf{1 . 6 2}$ & $\mathbf{0 . 7 3}$ \\
EF analysis & EFZn $<1$ & EFAs $<1$ & EFCo $<1$ & EFCu $<1$ & EFNi $<1$ & EFPb > 1 & EFMn $<1$ \\
\hline
\end{tabular}

Apart from ship traffic, the region is also a very busy area in terms of agricultural activities.

Olive cultivation is particularly intensive in the region (Fig. 9). It is seen that olive farming is done entirely in the land areas around the study area. This is shown on the Turkey Olive Production Map (https://s.milimaj.com/others/image/harita/turkiye-2019zeytin-uretim-haritasi.png) released by the Turkey Statistical Institute. 
Table 11. Enrichment factor calculations of Core samples (Core-1. Core-2. Core-3. Core-4)

\begin{tabular}{c|c|c|c|c|c|c|c}
\hline & EF ZN & EF AS & EF CO & EF CU & EF NI & EF PB & EF MN \\
\hline GMK/CORE-1 & 0.21 & 0.02 & 0.9 & 0.92 & 0.43 & 0.73 & 0.4 \\
EF analysis & EFZn $<1$ & $\mathrm{EFAs}<1$ & $\mathrm{EFCo}<1$ & $\mathrm{EFCu}<1$ & $\mathrm{EFNi}<1$ & $\mathrm{EFPb}<1$ & $\mathrm{EFMn}<1$ \\
GMK/CORE-2 & 0.29 & 0.03 & 0.93 & 0.84 & 0.48 & 0.56 & 0.64 \\
EF analysis & $\mathrm{EFZn}<1$ & $\mathrm{EFAs}<1$ & $\mathrm{EFCo}<1$ & $\mathrm{EFCu}<1$ & $\mathrm{EFNi}<1$ & $\mathrm{EFPb}<1$ & $\mathrm{EFMn}<1$ \\
$\mathrm{GMK} /$ CORE-3 & 0.45 & 0.02 & 0.88 & 0.85 & 0.41 & 0.6 & 0.49 \\
$\mathrm{EF}$ analysis & $\mathrm{EFZn}<1$ & $\mathrm{EFAs}<1$ & $\mathrm{EFCo}<1$ & $\mathrm{EFCu}<1$ & $\mathrm{EFNi}<1$ & $\mathrm{EFPb}<1$ & $\mathrm{EFMn}<1$ \\
$\mathrm{GMK} /$ CORE-4 & 0.49 & 0.01 & 0.96 & 0.78 & 0.63 & 0.78 & 0.78 \\
EF analysis & $\mathrm{EFZn}<1$ & $\mathrm{EFAs}<1$ & $\mathrm{EFCo}<1$ & $\mathrm{EFCu}<1$ & $\mathrm{EFNi}<1$ & $\mathrm{EFPb}<1$ & $\mathrm{EFMn}<1$ \\
\hline
\end{tabular}

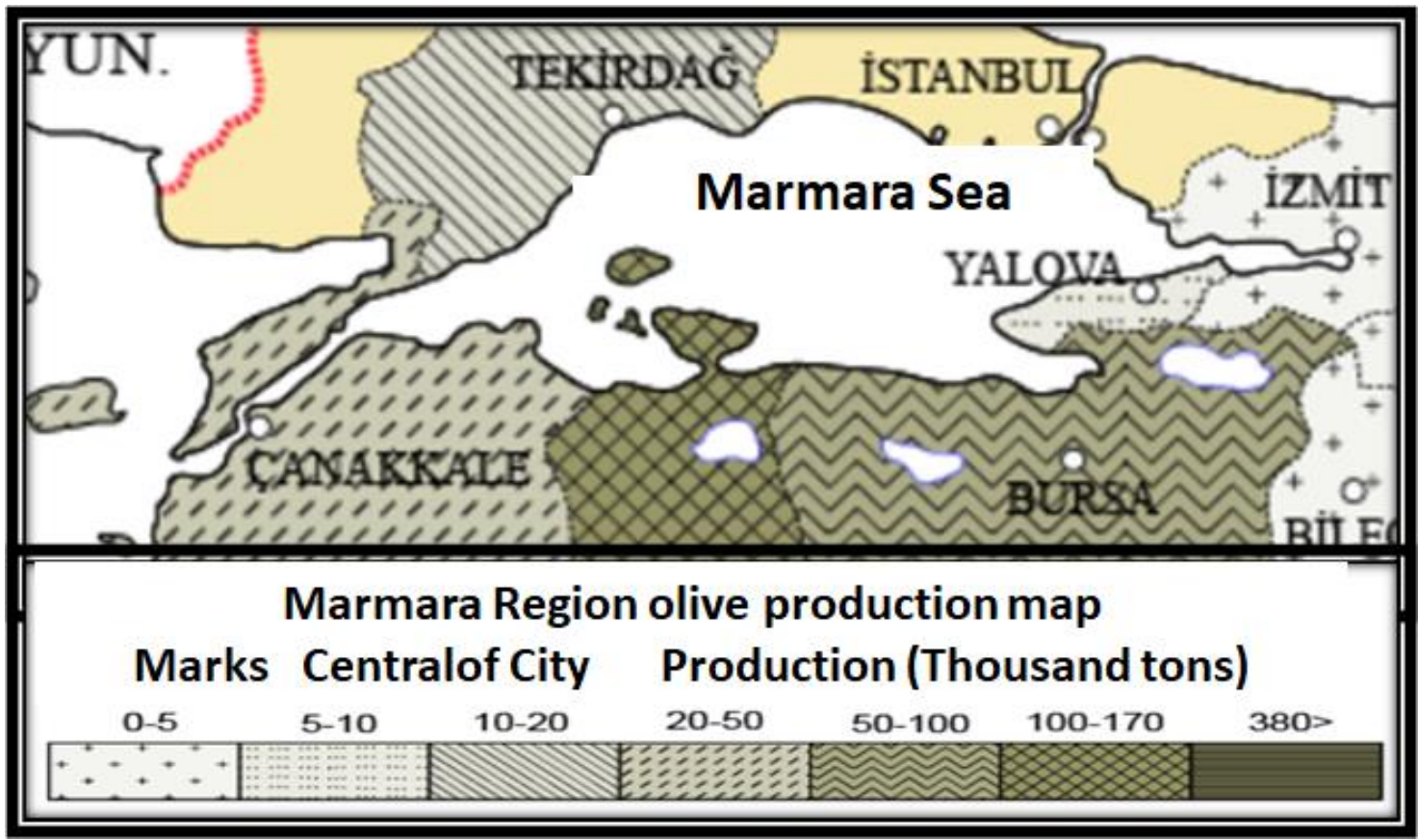

Figure 9. Olive production density map around Gemlik (Bursa/Turkey)

(https://s.milimaj.com/others/image/harita/turkiye-2019-zeytin-uretim-haritasi.png)

\section{Conclusions}

In this study, the heavy metal and radioactive pollution of Gemlik Bay was investigated. Two drillings (BH-1 and $\mathrm{BH}-2)$ were conducted and four core samples (CORE-1, CORE-2, CORE-3 and CORE-4) were taken from the gulf. According to the results of geochemical analysis, $\mathrm{Ag}, \mathrm{Bi}, \mathrm{Mo}, \mathrm{Sn}$ and $\mathrm{Se}$ concentrations were determined as 0 ppm in all samples. In Gemlik BH-1 drilling, in addition to other elements, mercury $(\mathrm{Hg})$ was detected at $0 \mathrm{ppm}$. The concentration values of $\mathrm{Zn}, \mathrm{As}, \mathrm{B}, \mathrm{Cd}, \mathrm{Co}, \mathrm{Cr}, \mathrm{Cu}, \mathrm{Ni}$ $\mathrm{Pb}, \mathrm{Pt}$ and $\mathrm{Sb}$ are between 0-300 ppm, and these elements are defined as the first group of elements. The concentration values of $\mathrm{Na}, \mathrm{Mg}, \mathrm{K}, \mathrm{Ca}, \mathrm{P}, \mathrm{S}, \mathrm{Fe}, \mathrm{Al}$ and $\mathrm{Mn}$ have been determined to be $>300 \mathrm{ppm}$, and these elements have been evaluated as the second group in this study. The pollution index (PI) values have been calculated by using the results of elemental analysis. Pollution-zone maps were created with the Kriging method by using pollution parameters obtained in this way. The pollution-zone map 
shows that Narlı (Gemlik-Bursa) and Büyükkumla (Gemlik-Bursa) and Kursunlu, Gemlik Fistıklı and Kumyaka have values approximately PI > 1, indicating a dangerous level of pollution. The pollution between Kumkaya, Fistıklı and Narlı (Gemlik-Bursa) and Büyükkumla (Gemlik-Bursa) is thought to be caused by agricultural activities and ship traffic. The pollution in Gemlik and Kursunlu is thought to be caused by industrial wastes, agriculture and ship traffic. In addition, using the results of the Fe, Zn, As, Co, $\mathrm{Cu}, \mathrm{Mn}, \mathrm{Ni}$ and $\mathrm{Pb}$ heavy metals analysis, the enrichment factor of each heavy metal (EF) was calculated. According to the enrichment factor results, EFNi in the BH-1 drilling is in the range of $3<\mathrm{EFNi}<5$, and other $\mathrm{EF}$ values are below 1 . The results obtained in this study were compared with the study given below. The calculated EF value result is close to $1(\mathrm{EF}<1)$ depending on the earth crust origin. The fact that the enrichment values are between 3 and 5 is controversial depending on the shell origin. EF $>5$ values are considered to be nonshell origin (Galuszka et al., 2014; Halstead et al., 2000). Since the EF value obtained in this study is less than 3, it is thought to be Earth Crust Origin.

The fact that the EFNi value is between 3 and 5 indicates that $\mathrm{Ni}$ is becoming enriched in the region. Specifically, the enrichment of Ni shows that the drainage waters of agricultural origin pollute the area. Natural and artificial radionuclides have been measured by radiological analyses, and the environmental and artificial radioactivity results of Gemlik Bay and its surroundings have been determined. The Ra-226 value has been found to be below the world average value at all locations. It is estimated that the K-40 values above the world average values in the BH-1 drilling are from the intensive agricultural activities in that part of the study area. However, K-40 values are below the average in the $\mathrm{BH}-2$ drillings. There is little or no agricultural activity on the land near the $\mathrm{BH}-2$ drilling zone. Th-232 values have been found to be above the world average value $(30 \mathrm{~Bq} / \mathrm{kg})$ in $\mathrm{BH}-2 / 3(39.85 \mathrm{~Bq} / \mathrm{kg})$ but below that value in other locations. The Cs-137 value has reached the highest value by exceeding $5.3 \mathrm{~Bq} / \mathrm{kg}$ in the $\mathrm{BH}-1 / 1$ drilling. The fact that Cs-137 is high in the upper level of the drilling draws attention to the presence of artificial radioactivity. The fact that the Cs-137 radionuclide increased above the measurable limit at this location revealed the level of impact of nuclear activity on the region. In other locations, Cs-137 is at the background level. In the core samples, the K-40 value has been found to be the highest in Kurşunlu $(498 \mathrm{~Bq} / \mathrm{kg})$, and this value is above the world average value. The value of Th-232 is the highest in Fist1kl1 $(42,82 \mathrm{~Bq} / \mathrm{kg})$, and this value is above the average value. The Ra226 value has been found to be the highest in Fistikl1, but this value is below the average value.

The Pollution Index was obtained as $>1$ in core samples and $<1$ on average values of the drilling samples. This situation shows that pollution has increased in marine environment in the current period. It is seen that Radioactivity is also high in places where the Pollution Index is high. This shows that there is a close relationship between elemental pollution and radioactive pollution. An example of this is the fact that Cs-137 $(5.3 \pm 29.21)$ values are higher in samples taken from the upper level of GMK-1 boring, and the background value of CS-137 in samples taken from below level. Again, the radioactivity values obtained in Core-3 samples are above the world average values and the PI value is $>1$, which is an important data for showing environmental pollution. It is possible to say the same situation within the enrichment factor. In order to determine the environmental pollution, there was a parallelism between Pollution Index, Enrichment Factor and Radioactivity analysis. 
Acknowledgements. The authors thank the RORO Company and the Gemlik Harbour Authority for their support, and the Namık Kemal University Central Research Laboratory (NABILTEM) for the geochemical analysis, and the Çekmece Nuclear Energy Agency for radiological analysis. The author also thanks Yildiz Technical University Scientific Research Projects Commission for accepting and financing this study (Project no: FBA-2018-3351) and Tekirdağ Namik Kemal University Scientific Research Projects Commission for accepting and financing this study (Project no: NKUBAP.42.GA.19.193)

\section{REFERENCES}

[1] Adamo, P., Arienzo, M., Imperato, M., Naimo, D., Nardi, G., Stanzione, D. (2005): Distribution and partition of heavy metals in surface and sub-surface sediments of Naples city port. - Chemosphere 61: 800-809.

[2] Akçay, H., Oğuz, A., Karapire, C. (2003): Study of heavy metal pollution and speciation in Buyak Menderes and Gediz river sediments. - Water Research 37: 813-822.

[3] Alpar, B., Ünlü, S., Kırbaşıoğlu, C. (2006): Records of anthropogenic pollution in sediment of Gemlik Bay (Marmara Sea, Turkey) during the last 15 years. - Geophysical Research Abstracts 8: 00392.

[4] ASTM E181-98 (2003): Standard Test Methods for Detector Calibration and Analysis of Radionuclides. - ASTM, West Conshohocken, PA.

[5] Bampton, M. (1999): Anthropogenic Transformation. - In: Environmental Geology. Encyclopedia of Earth Science. Springer, Dordrecht. https://doi.org/10.1007/1-40204494-1_17.

[6] Baptista Neto, J. A., Smith, B. J., Mc Allister, J. J. (2000): Heavy Metal Concentrations in Surface Sediments in a Nearshore Environment, Jurujuba Sound, Southeast Brazil. Environmental Pollution 109: 1-9.

[7] Buat-Menard, P., Chesselet, R. (1979): Variable in fluence of the atmospheric flux on the trace metal chemistry of oceanic suspended matter. - Earth Planet Science Lett 42: 399411.

[8] Dickinson, W. W., Dunbar, G. B., Mc Leod, H. (1996): Heavy metal history from cores in Wellington Harbour, New Zealand. - Environmental Geology 27: 59-69.

[9] Esen, E., Kucuksezgin, F., Uluturhan, E. (2008): Assessment of trace metal pollution in surface sediments of Nemrut Bay, Aegean Sea. - Environmental Monitoring and Assessment 160(1-4): 257-266.

[10] Essien, J. P., Antai, S. P., Olajire, A. A. (2009): Distribution, seasonal variations and ecotoxicological significance of heavy metals in sediments of cross river estuary mangrove swamp. - Water, Air, and Soil Pollution 197: 91-105.

[11] Feng, H., Cochran, J. K., Lwiza, H., Brownawell, B. J., Hirschberg, D. J. (1998): Disribution of heavy metal and PCB contaminants in the sediments of an urban estuary: the Hudson River. - Marine Environmental Research 45: 69-88.

[12] Galuszka, A., Migaszewski, Z. M., Zalasiewicz, J. (2014): Assessing the Anthropocene with geochemical methods. - Geological Society, London, Special Publications 395: 221238.

[13] Gao, X. L., Chen, C. T. A. (2012): Heavy metal pollution status in surface sediments of the coastal Bohai Bay. - Water Res 46: 1901-1911.

[14] Halstead, M. J., Cunninghame, R. G., Hunter, K. A. (2000): Wet deposition of trace metals to a remote site in Fiordland, New Zealand. - Atmospheric Environment 34: 665676.

[15] Hornung, H., Karm, M. D., Cohen, Y. (1989): Trace metal distribution on sediments and benthic fauna of Haifa Bay, Israel. - Estuarine, Coastal and Shelf Science 29: 43-56.

[16] https://desktop.arcgis.com/en/arcmap/10.3/tools/3d-analyst-toolbox/how-krigingworks.htm\#: :text=Kriging\%20is\%20a\%20multistep\%20process, directional\%20bias\%20 in\%20the\%20data. 
[17] Huerta-Diaz, M. A., Delgadillo-Hinojosa, F., Hernández-Ayón, M., Segovia-Zavala, J. A., García-Esquivel, Z., López-Zárate, H., Siqueiros- Valencia, A., Galindo-Bect, S. (2008): Diagnosis of trace metal contamination in sediments: the example of Ensenada and El Sauzal, two harbors in Baja California, Mexico. - Marine Environmental Research 66: 345-358.

[18] Kam, E., Önce, M. (2016): Pollution potential of heavy metals in the current sea sedıments between bandırma (Balıkesir) and lapseki (Çanakkale) in the marmara sea. Journal of Engineering Technology and Applied Sciences 1: 141-148.

[19] Koday, S., Baki, G. (2014): Port of Gemlik. - Atatürk University Journal of the Institute of Social Sciences 18: 431-454.

[20] Mason, B. J., Moore, C. B. (1982): Principles of Geochemistry. 4th Ed. - Wiley, New York.

[21] Meriç, E., Avşar, N., Nazik, A., Alpar, B., Yokeş, B., Barut, İ. F., Ünlü, S. (2005): Foraminifera, ostrakod and mollusc fauna of gemlik bay surface sediments, sedimentological, hydrochemical and biochemical properties of the region with morphological abnormalities observed in foraminiferal shells. - Journal of Mining Tetics Search 131: 21-48.

[22] Mohiuddin, K. M., Zakir, H. M., Otomo, K., Sharmin, S., Shikazono, N. (2010): Geochemical distribution of trace metal pollutants in water and sediments of downstream of an urban river. - International Journal of Environmental Science and Technology 7: 17-28.

[23] Morillo, J., Usero, J., Gracia, I. (2002): Heavy metal fractionation in sediments from the Tinto River (Spain). - International Journal of Environmental \& Analytical Chemistry 82: 245-257.

[24] Okuş, E., Balkıs, N., Müftüoglu, E., Aksu, A. (2007): Metal (Pb, Cd and Hg) inputs via the rivers to the Southern Marmara Sea Shelf, Turkey. - J. Black Sea/Medit. Environ. 13. http:// www.blackmeditjournal.org/index.asp (accessed: April 1, 2014).

[25] Omgbu, J. A., Kokogbo, M. A. (1993): Determination of $\mathrm{Zn}, \mathrm{Pb}, \mathrm{Cn}$ and $\mathrm{Hg}$ in soils of Ekpan, Nigeria. - Environ Int 19: 611-612.

[26] Park, J., Presley, B. J. (1997): Trace metal contamination of sediments and organisms from the Swan Lake area of Galveston Bay. - Environmental Pollution 98: 209-221.

[27] Pekey, H. (2006): The distribution and sources of heavy metals in Izmit Bay surface sediments affected by a polluted stream. - Marine Pollution Bulletin 52(10): 1197-1208.

[28] Ray, A. K., Tripathy, S. C., Patra, S., Sarma, V. V. (2006): Assessment of Godavari estuarine mangrove ecosystem through trace metal studies. - Environment International 32: $219-223$.

[29] Riemann, L., Steward, G. F., Azam, F. (2000): Dynamics of bacterial community composition and activity during a mesocosm diatom bloom. - Applied and Environmental Microbiology 66: 578-587.

[30] Schiff, K. C., Weisberg, S. B. (1999): Iron as a reference element for determining trace meta enrichment in southern California coastal shelf sediments. - Marine Environmental Research 48: 161-176.

[31] Sutherland, B. R. (2000): Internal wave reflection in uniform shear. - Quarterly Journal of the Royal Meteorological Society 126: 3255-3286.

[32] Taylor, S. R., Mc Lennan, S. M. (1995): The geochemical evolution of the continental crust. - Reviews of Geophysics 33: 241-265.

[33] TSE ISO 14869-1 (2004a): Soil Quality - Dissolution for the Determination of Total Element Content - Part 1: Dissolution with Hydrofluoric and Perchloric Acids. - TSE (Turkish Standardized Institute), Ankara.

[34] TSE ISO 14869-2 (2004b): Soil Quality - Dissolution for the Determination of Total Element Content - Part 2: Dissolution with Alkaline Fusion. - TSE (Turkish Standardized Institute), Ankara. 
[35] Ünlü, S., Alpar, B. (2006): Distribution and sources of hydrocarbons in surface sediments of Gemlik Bay (Marmara Sea, Turkey). - Chem. 64: 764-777.

[36] UNSCEAR (2000): United Nations. Sources and Effects of Ionizing Radiation. Volume I: United Nations Scientific Committee on the Effects of Atomic Radiation, 2000 Report to the General Assembly, with scientific annexes. - United Nations Sales Publication E.00.IX.3 and E.00.IX.3. United Nations, New York.

[37] Valdés, J., Vargas, G., Sifeddine, A., Ortlieb, L., Guinez, M. (2005): Distribution and enrichment evaluation of heavy metals in Mejillones Bay (23oS), Northern Chile: geochemical and statistical approach. - Marine Pollution Bulletin 50: 1558-1568.

[38] Yümün, Z. Ü. (2017): The Effect of heavy metal pollution on foraminifera in the western Marmara Sea (Turkey). - Journal of African Earth Sciences 129: 346-365.

[39] Yümün, Z. Ü., Kam, E. (2017): Effects of radionuclides on the recent foraminifera from the clastic sediments of the Çanakkale Strait-Turkey. - Journal of African Earth Science 131: 179-182.

[40] Yümün, Z. Ü., Önce, M. (2017): Monitoring heavy metal pollution in foraminifera from the Gulf of Edremit (northeastern Aegean Sea) between Izmir, Balıkesir and Çanakkale (Turkey). - Journal of African Earth Sciences 130: 110-124.

[41] Zhang, C., Qiao, Q., Piper, J. D., Huang, B. (2011): Assessment of heavy metal pollution from a Fe-smelting plant in urban river sediments using environmental magnetic and geochemical methods. - Environmental Pollution 159: 3057-3070. 